Taxing Multinationals beyond borders

Financial and Locational Responses to CFC Rules

Clifford, Sarah

Publication date:

2017

Citation for published version (APA):

Clifford, S. (2017). Taxing Multinationals beyond borders: Financial and Locational Responses to CFC Rules. EPRU Working Paper Series Vol. 2017 No. 02 http://web.econ.ku.dk/eprn_epru/Workings_Papers/WP-201702.pdf 
Economic Policy Research Unit

Department of Economics

University of Copenhagen

$\emptyset$ ster Farimagsgade 5, Building 26

DK-1353 Copenhagen K

DENMARK

Tel: (+45) 35323010

Fax: (+45) 35323000

Web: http://www.econ.ku.dk/epru/

Taxing multinationals beyond borders: financial and locational responses to CFC rules

Sarah Clifford 


\title{
TAXing MULTinAtionAls BEYOND BORDERS: FinANCIAL AND LOCATIONAL RESPONSES TO CFC RULES
}

\author{
Sarah Clifford ${ }^{\dagger}$
}

June 20, 2017

Using a large panel dataset on worldwide operations of multinational firms, this paper studies one of the most advocated anti-tax-avoidance measures: Controlled Foreign Corporation rules. By including income of foreign low-tax subsidiaries in the domestic tax base, these rules create incentives for multinationals to move income away from low-tax environments. Exploiting variation around the tax threshold used to identify low-tax subsidiaries, we find that multinationals redirect profits into subsidiaries just above the threshold and place more new subsidiaries just above compared to just below the threshold. The resulting increase in global corporate tax revenue partly accrues to the rule-enforcing country.

Keywords: CFC legislation $\cdot$ Multinational firms $\cdot$ Tax avoidance $\cdot$ Corporate taxation JEL classification: F23, H25, K34

\footnotetext{
${ }^{\dagger}$ Department of Economics, University of Copenhagen, Øster Farimagsgade 5, 1353 Copenhagen K, Denmark (e-mail: sarah.clifford@econ.ku.dk). I acknowledge financial support from the Danish Council for Independent Research. I thank Simon Boserup, Niels Johannesen, Henrik Kleven, Claus Thustrup Kreiner, Panos Mavrokonstantis and Benjamin Ly Serena for helpful comments and suggestions. Furthermore I gratefully acknowledge the useful comments and suggestions from participants at the DGPE 2016 workshop, UCPH Economic Policy Research Unit seminar and LSE Public wip seminar. All remaining errors are my own.
} 


\section{INTRODUCTION}

The combination of a globally integrated market and sizeable tax rate differentials has created a foundation for tax planning opportunities. In 2014 thousands of documents surfaced in Luxembourg giving the public rare insight into the concrete tax avoidance schemes of large multinational enterprises. Evidence from this so-called Luxleaks scandal resonates with an empirical literature documenting substantial tax-related profit shifting (Huizinga \& Laeven 2008, Heckemeyer \& Overesch 2013, Dharmapala \& Riedel 2013). Resulting losses on global corporate tax revenues are considerable. Zucman (2014) estimates that the use of low-tax jurisdictions by multinational firms is associated with a 20 percent reduction in the taxes paid by US owned corporations.

In response to this comprehensive migration of profits to low-tax environments, many countries have extended their international tax policy rules with anti-tax-avoidance measures designed to curb profit shifting. One of the most important examples is a set of rules known as Controlled Foreign Corporation (CFC) legislation. The importance of this measure is reflected in its global prevalence as well as in the political debate where the measure is highly advocated by the OECD in their 2015 report on base erosion and profit shifting (BEPS). Around two thirds of the OECD countries have CFC legislation and several of the remaining nations are debating the introduction of such a regime.

CFC rules impose an immediate and direct tax on selected parts of the income of low-tax foreign subsidiaries. The German rules constitute a typical example of the CFC regimes in place across the world. Germany classifies any foreign subsidiary taxed at a rate lower than 25 percent as a low-tax subsidiary, and targets income types such as interest and royalty income from such subsidiaries. Consequently, the German CFC rules work by including the interest and royalty income of foreign subsidiaries facing a tax rate below 25 percent in the German corporate tax base and taxing this income at the much higher German corporate tax rate. Though CFC legislation varies across countries, the German setup is highly representative important for the empiric design in this paper most countries set a low-tax threshold as the German 25 percent cut-off.

From a pure tax perspective, these rules create an incentive for multinationals to move income 
types such as interest income away from low-tax subsidiaries and into higher tax host countries just above the specified threshold. In line with the incentive to relocate income, they create an incentive to reorganize geographical firm structure and open new subsidiaries in higher tax environments above the threshold.

One obvious objective of this direct tax is to protect the domestic tax base by eliminating incentives for geographical relocation of profits to foreign low-tax subsidiaries. When profits can escape the reach of domestic tax rules it threatens the enforceability of these rules and ultimately the ability of governments to collect tax revenue. Base protection and enforceability in general are integral parts of a country's tax system and are crucial for the feasibility of optimal tax policy design.

In this paper, we explore the potential of CFC rules in obtaining this objective by studying the behavioural responses of multinational firms to the CFC measure. Tracking these responses allows us to investigate how the financial and locational structures within multinationals change in response to this anti-tax-avoidance rule. The analysis draws on a large global dataset containing subsidiary-level panel data from more than 200 countries and spanning 22 CFC regimes. With its global reach and panel structure the data enables both within-group and within-subsidiary analysis using exogenous reform variation. We exploit changes in CFC treatment status created by the interplay of the low-tax threshold and general tax reforms. When Finland lowered its corporate tax rate to 24.5 percent in 2012 Finnish subsidiaries within German multinationals were moved across the German CFC threshold triggering potential CFC taxation by Germany. Given a sample period of more than ten years such examples are numerous.

Throughout we uncover sizeable behavioural responses to the CFC tax measure. Considering the distribution of financial profit around the low-tax threshold, we observe a sharp discontinuous increase just at the threshold value. Such non-parametric graphical evidence is supported by a simple within-group comparison of targeted subsidiaries below the threshold and non-targeted subsidiaries above, revealing a 20 percent difference in the level of financial profit. This simple comparison exploits both within-subsidiary time variation and betweensubsidiary cross-sectional variation around the threshold. We isolate each source of variation and show that the two sources provide estimates of a very similar magnitude. When a reform 
moves a subsidiary below the CFC tax threshold, we estimate a 14 percent subsequent drop in financial profit within the subsidiary. This suggests that CFC rules, by imposing a potential tax penalty, induce multinationals to move substantial amounts of income out of very low-tax environments.

To understand the underlying group behaviour causing this drop in profits within low-tax subsidiaries, we broaden the focus from the single subsidiary to the entire multinational group. The number of within-group subsidiaries placed below the tax threshold is a measure of groupexposure to the CFC policy. Using variation in such measures, we present evidence that higher exposure leads to increases in financial profit in higher tax environments outside the scope of the legislation. The combination of these results points to an underlying shifting mechanism within multinationals going from low-tax targeted subsidiaries to higher tax subsidiaries. Among the recipients are also domestic corporations, meaning that the use of the CFC instrument to target foreign subsidiaries leads to an increase in the domestic corporate tax base. In essence, we present evidence that the measure can be used by the rule-enforcing country to create a global as well as a domestic tax revenue gain without coordinating with other countries. This domestic component in the revenue gain is potentially important in a context of international tax policy where the need for coordination has been highlighted as crucial for a successful fight against tax avoidance (OECD/G20, 2015) ${ }^{1}$.

While the allocation of income is perhaps the most proximate margin of response, extensive margin responses on firm structure also seem highly plausible. Using both the timing and location of newly incorporated subsidiaries, we find that CFC legislation affects the geographical structure of multinational firms. Instead of relying on the standard conditional logit framework for the analysis of locational choices, we introduce an alternative approach exploiting the choices of unaffected groups to account for non-CFC related differences between alternatives. This allows us to present non-parametric graphical evidence on extensive margin responses, showing a clear discontinuity at the tax threshold. Groups affected by a CFC regime display a higher propensity to choose host countries placed just above the tax threshold and a lower

\footnotetext{
${ }^{1}$ The OECD/G20 write in their Base Erosion and Profit Shifting (BEPS) Project, 2015 report: "The G20 and the OECD have recognised that BEPS by its very nature requires coordinated responses, which is why countries have invested the resources to participate in the development of shared solutions".
} 
propensity to choose hosts just below the threshold compared to groups who are not based under a regime.

Despite the large monetary sums involved and the potential relevance for tax policy design, behavioural responses to CFC rules have so far received very limited attention. Altshuler \& Hubbard (2002) focus on a reform from 1986 of the US CFC rules and use country-level aggregate data on asset holdings to show that certain US owned firms become less sensitive to host country tax rates after a tightening of the rules. ${ }^{2}$ Ruf \& Weichenrieder (2012) study the asset allocation within German multinational groups and conclude that CFC rules affect the geographical pattern of asset holdings. Egger \& Wamser (2015) introduce a multi-dimensional regression discontinuity design to analyse the effect of CFC legislation on the allocation of foreign real investments of German multinationals. They also find substantial differences across subsidiaries treated differentially by the rules. ${ }^{3}$

This paper contributes to the literature on CFC rules and tax avoidance in several dimensions. We present the first non-parametric graphical evidence showing discontinuities created by CFC legislation. Such graphical evidence is provided both for the intensive margin of income allocation and for the extensive margin of subsidiary location. On the intensive margin, we directly study generated profits within multinational corporations. While previous literature has focused solely on the allocation of assets, we concentrate on the actual object of taxation and thereby avoid assumptions on the relationship between asset value and income flows. In essence, we use an outcome that directly reflects the corporate tax base of countries. Further, we present the first evidence on the consequences of CFC legislation for the domestic corporate tax base. Identifying a domestic component within the global tax base response is potentially crucial for policy makers with national objectives of creating tax revenue by fighting corporate tax base erosion.

The remaining main contributions are related to identification issues and elimination of poten-

\footnotetext{
${ }^{2}$ Mutti \& Grubert (2007) show however, that after the 1997 implementation of check-the-box rules, US multinationals can avoid triggering the US CFC rules by creating hybrid entities.

${ }^{3} \mathrm{~A}$ small theoretical literature on CFC rules exists. Weichenrieder (1996) shows that an exogenously imposed CFC rule increases the cost of capital for treated foreign subsidiaries, while Haufler et al. (2017) endogenize the choice of a CFC rule in an optimal tax framework. Within this framework, they derive conditions for the optimality of a CFC rule in combination with other tax instruments.
} 
tial biases. We present the first micro-study of CFC rules isolating within-subsidiary responses to exogenous variation in CFC targeting. The reach of the dataset enables specifications relying solely on time variation from tax reforms affecting foreign subsidiaries differentially.

Further, we depart from the one country case and instead introduce a comprehensive multicountry framework covering $22 \mathrm{CFC}$ policy regimes. Studying multinationals from a single home country and hence a single policy regime means that any reform of the tax component determining CFC treatment will affect all subsidiaries within the same foreign host country identically. Introducing a second home country secures variation across subsidiaries within the same host country. This variation is essential because it provides control groups to account for the confounding influence of changes in market conditions affecting corporations operating on a specific market. The multiple country framework hereby allows us to present a study isolating within-subsidiary variation while controlling for market time-trends to identify causal effects of CFC legislation.

Our analysis also contributes to a second strand of literature dealing with the tax determinants of the location choices within multinationals. Barrios et. al. (2012) find that the subsidiary location choice within multinational corporations is sensitive to taxes in several dimensions - both host country corporate taxes and parent-country tax rules affecting foreign income. Buettner \& Ruf (2007) find a high sensitivity especially to statutory tax rates in host countries using a sample of German multinational corporations. Devereux and Griffith (1998) find an effect of average effective tax rates on the foreign location choices of US multinationals. Voget (2011) looks at the decision to relocate headquarters and finds an increased probability of relocation for multinationals headquartered in home countries with higher tax levels on foreign repatriated income. He introduces a dummy for the presence of a CFC regime in the headquarter-country, and concludes that such legislation increases the probability of relocation. ${ }^{4}$

We contribute to this literature by investigating the consequences of the CFC anti-taxavoidance measure for the geographical pattern of subsidiaries within multinational firms. The pure extensive margin of response is a yet unexplored margin in the context of this tax

\footnotetext{
${ }^{4}$ For a survey of empirical evidence on the effect of taxation on firm-choices see Devereux \& Maffini (2007)
} 
measure. ${ }^{5}$ By investigating the pattern of new incorporations around the tax threshold of CFC affected groups relative to unaffected groups, we show significant causal responses.

The rest of the paper is organized as follows: section II describes the international tax environment facing corporate groups and explains in detail the components of CFC legislation. Section III introduces the data used for the empirical analysis while section IV puts forward brief theoretical considerations on the incentives created by CFC rules. Section IV furthermore presents a short overview of the empirical design before section $\mathrm{V}$ presents the main results. Section VI concludes.

\section{The International TAX EnVIRONMENT FOR CORPORATE GROUPS}

A salient feature of the corporate landscape today is a remarkably high level of global integration. Such integration complicates taxation of corporate income and renders corporate tax policy a border crossing issue. Consider a multinational group comprising a parent and several subsidiaries. When profit is generated in both the home country of the parent and in one or several of the subsidiary host countries, a fundamental question arises of how this income should be taxed. Most jurisdictions accept the premise that all corporations in the structure are separate taxpayers and hence each subsidiary is subject to corporate income tax in the host country of incorporation. However, due to the ownership structure of the group all profits are essentially owned by the parent company and this entity can determine a partial or full repatriation of the income at any point in time. To avoid double taxation most home countries operate an exemption system when within-group profits are remitted. This effectively means that such income is not subject to further taxation by the home country when received by the parent ${ }^{6}$. While this method solves the problem of double taxation it evidently

\footnotetext{
${ }^{5}$ Ruf \& Weichenrieder (2012) present an analysis of the asset allocation choice within multinationals, which is slightly related in the sense that they model the geographic location choice of large amounts of passive assets using a conditional logit framework.

${ }^{6} \mathrm{~A}$ few countries, most notably the US, opt for a credit system instead of an exemption system. Under a credit system the income is taxed when repatriated to the home country, but a credit is given for all foreign taxes already paid.
} 
also leaves scope for tax planning using host countries with low tax rates. With the objective of protecting their domestic corporate tax base, high tax home countries have an interest in minimizing potential abuse of this scope.

\section{Controlled Foreign Corporation (CFC) Rules}

In an attempt to control such tax planning, many countries have introduced so-called Controlled Foreign Corporation $(C F C)$ rules. This policy introduces a potential direct tax on foreign subsidiaries of domestic corporations. Consider a multinational firm consisting of three entities - a parent corporation in Germany, a fully owned subsidiary in Ireland and a fully owned subsidiary in France. CFC legislation in Germany will place a tax on the interest income of the Irish subsidiary since Ireland has a low tax rate, while the interest income of the French subsidiary will remain untaxed by Germany because France already taxes the income at a high rate. ${ }^{7}$ Broadly, CFC legislation enables the home country to directly tax the income of foreign subsidiaries, if this foreign income lives up to certain criteria. Included criteria vary slightly across regimes, but they tend to include three basic components: a control-, a tax level- and an income source criterion. In consequence, the part of the income of foreign subsidiaries which is most likely to be involved in tax avoidance strategies, is included in the tax base of the parent corporation and taxed directly by the home country. We briefly explain the common features of each criterion to clarify the incentives created by this type of tax legislation.

The control criterion ensures that the shareholder is in possession of control over financial decisions of the subsidiary and is hence able to utilise this ownership privilege for tax avoidance purposes. Most CFC regimes that are currently in place require ownership of the majority of voting rights or some financial right such as the right to profit upon distribution. In the example above, the German parent must have control over the financial decisions of the Irish subsidiary for CFC rules to activate.

The tax-level criterion is included to embed a focus on low taxed income as this seems a logical

\footnotetext{
${ }^{7}$ It is possible that the interest income of the Irish subsidiary can be exempt from the rules, if the subsidiary has enough active business income. Such specific details of each set of rules are explained in table 7 .
} 
trait of income used as a vehicle for avoidance motives. Typically this requirement takes the form of a fixed minimum tax level calculated by looking at the actual taxes paid. This level can be stated as a fixed absolute rate, or as a percentage of the calculated tax liability had the subsidiary been liable for taxation in the parent country. It is only the Irish subsidiary and not the French that is targeted by the German CFC regime, because Ireland has a low tax rate on corporate profits while France does not.

The final criterion concentrates on the source of the income. Most often legislation targets only passive (or tainted) income. The term passive income generally covers sources such as financial income from portfolio holdings, certain types of rental income and royalties from intellectual property. These types of income are perceived as very mobile making them ideal for income shifting with avoidance motives. Income of the Irish subsidiary earned through sales of actual products is not affected by the German CFC rules while interest income is affected and potentially taxed by Germany.

If a subsidiary fulfils all specified criteria, the passive income of the subsidiary is included in the tax base of the parent corporation and taxed at the rate of the home country. The taxation takes place on accrual basis, and is not postponed until a potential repatriation. Overall this creates an incentive for multinationals to generate passive income in higher tax environments, than would otherwise have been optimal absent the legislation.

The data source underlying our empirical analysis allows us to potentially look at multinational firms from 57 different parent countries of which 22 have a CFC regime in some part of the sample period. A simplified overview of these 22 regimes is given in the Appendix Table 7. This table describes the specifics of each of the three aforementioned criteria for each separate country, as well as further details that are potentially relevant. An initial simple comparison between these 22 countries and the remaining sample countries reveals an interesting starting point. On average corporate multinational groups under a CFC regime appear to be generating passive income in higher tax environments compared to groups where the parent is located in a country with no such regime. This regularity is illustrated in Figure 1 showing the empirical cumulative distribution function across the range of corporate tax rates for financial profit. Each point represents the fraction of total positive financial profit generated 
in corporations facing a corporate tax rate below the specified value. The figure shows the pattern separately for groups with a parent based under a CFC regime, and for groups where the parent is unaffected by such rules. Importantly we observe a CDF for targeted groups that is consistently located below the CDF for non-targeted groups. This feature implies that groups facing a CFC regime tend to choose higher tax environments when it comes to the allocation of passive income. CFC targeted groups generate only 10 percent of their total positive financial profit in host countries with tax rates below 25 percent, while non-targeted groups generate 23 percent of positive financial profit in these low tax environments. Clearly there are considerable differences in the distributional patterns of passive income when we compare potentially targeted and non-targeted groups. The fundamental question is then whether this difference can be attributed to effective CFC legislation and subsequently what this means for global corporate tax revenues.

\section{DATA}

The data used throughout this paper originates from the Orbis database (2013 version) managed and updated by Bureau van Dijk. The database contains firm-level panel data across the period 2003-2013 on a large number of financial and organisational variables. The database specifically contains ownership links and percentages - a feature that enables the linkage of each company to its ultimate owner also referred to as parent corporation ${ }^{8}$. Since CFC legislation targets and taxes foreign subsidiaries of domestic corporations, the legislation that matters for a specific subsidiary is the legislation in place in the country of the company's parent. Hence the recorded ownership links make it possible to disentangle exactly which CFC regime is relevant for each particular subsidiary. ${ }^{9}$ Ownership links are only available

\footnotetext{
${ }^{8}$ The ultimate owner is here defined as the highest placed shareholder in the corporate structure who owns a majority of the shares in the subsidiary either directly or indirectly.

${ }^{9}$ In the case of ownership chains, situations can emerge where some doubt as to which country's CFC legislation is relevant can arise. To exemplify consider a German parent owning a French subsidiary which again owns an Irish subsidiary. If the Irish subsidiary fulfils the requirements of both the French and the German CFC rules, it can be unclear which CFC regime should activate. This kind of double CFC taxation is not explicitly dealt with in most regimes, but seems to be less of an issue in practice. Consequently we will abstract from this mostly theoretical issue and consider the legislation active in the country of the ultimately
} 
Figure 1:

\section{Empirical CDF of financial profit across corporate tax rates}

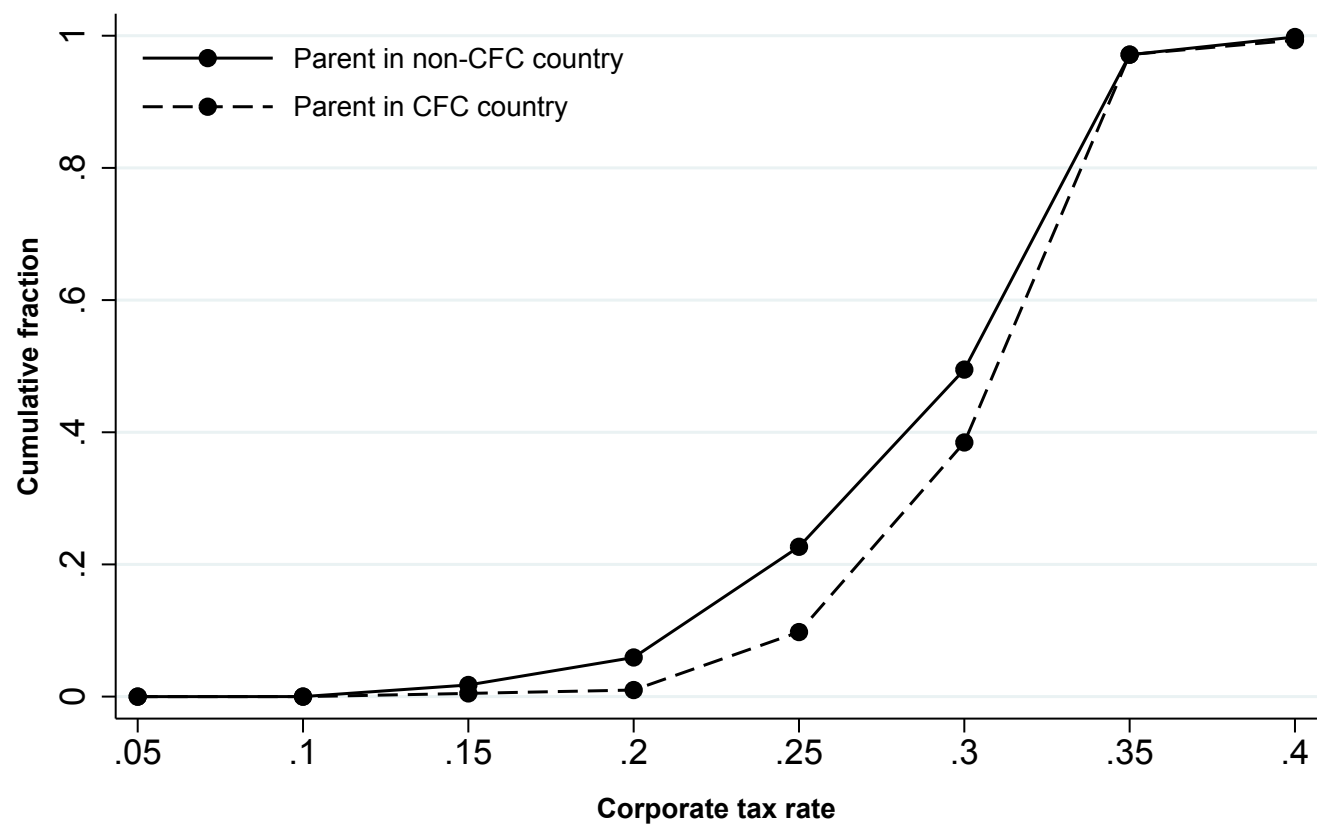

Notes: The figure is constructed using only observations with non-negative financial profit. Each point represents the fraction of total financial profit belonging to corporations located in countries with a corporate tax rate below or equal to the value indicated on the x-axis. All multinational groups are divided into two: those where the parent is located in a home country with a CFC regime and those where the parent is located in a home country with no CFC regime. We exclude all groups where the parent is situated in a tax haven, since investment patterns in these jurisdictions might be very distinct and not representative of investment patterns more generally. Including these observations results in very similar figures. All corporations in the multinational groups are considered - i.e. both the parent and (majority owned) domestic and foreign subsidiaries. Excluding the parent corporation results in a very similar figure.

in the database for the most recent date of information. To the extent that these ownership structures have changed in the period from 2003 to 2013, we are potentially misspecifying the link between parent and subsidiary in parts of the sample period. In line with other studies using this type of data, this is not considered a great concern, since such misspecification will create noise and should therefore only bias our results towards zero.

The final dataset contains multinational groups from 57 different home countries with subowner (here the German corporation) to be the relevant legislation. 
sidiaries in 207 different host countries. ${ }^{10}$ By a multinational group we mean a corporate construction consisting of a parent company and at least one foreign subsidiary. As mentioned 22 of these home countries have active CFC legislation in some part of the sample period, while 35 countries do not. Information on the legislation in place in each of these countries during the sample period was individually collected using different sources hereunder the International Fiscal Association (2013) and various legal documents.

The dataset is further extended with statutory tax rates from KPMG, Ernst \& Young and Deloitte, as well as country characteristics from the World Bank Development Indicators and Worldwide Governance Indicators. For geographical variables such as distance between countries we use CEPII databases, such as the GeoDist database. Descriptive statistics of subsidiary level financials, as well as group characteristics are given in the appendix table $4 .{ }^{11}$

Despite a coverage across $22 \mathrm{CFC}$ regimes, note that the dataset is not balanced across these countries, in the sense that some countries account for a large share of the total number of included multinational groups. In the Appendix Figure 6 we show the number of observations attributable to each of the 22 home countries on the main outcome variable. From this figure it is evident that there are indeed differences in coverage, however several policy regimes each contribute with a large number of observations alleviating the concern that results could be driven by few unrepresentative regimes.

\section{VARIATION AND EMPIRICAL METHODOLOGY}

Our objective of obtaining causal estimates of the effect of CFC taxation on both financial and locational outcomes requires some form of variation across or within foreign subsidiaries. Of the 22 sample countries with a CFC regime 18 have a low-tax criterion formulated directly

\footnotetext{
${ }^{10}$ Due to the time requirements accompanying collection of information on the legislation in place in each considered country, we have restricted the final dataset to include only multinational groups from countries where we have a sufficient number of subsidiary observations. The lower limit was set at 5000 subsidiaries before any additional sorting of the data. We do not in any way restrict host countries, but consider all recorded subsidiaries in the included multinational groups.

${ }^{11}$ In the first part of the paper when considering allocation of profits, we drop all observations where financial information is based on consolidated accounts, since we cannot disentangle the individual shares of each subsidiary.
} 
as a threshold value. The location of this threshold varies significantly across regimes, and within several countries we observe a shift in the threshold value during the sample period. These movements are often results of general tax reforms not directly related to the CFC rules, since thresholds can be specified as a percentage of own tax level. Such indirect level-changes arguably renders endogenous placement of thresholds less likely. Below we explain in more detail how tax conditions vary across this threshold and what types of incentives this creates for the multinational firm.

Denote the statutory corporate income tax rate in home country $j, \boldsymbol{\tau}_{j}$ and similarly denote the tax rate in host country $i, \boldsymbol{\tau}_{i}$. Assume that home country $j$ has a CFC regime in place with a low-tax threshold at $\alpha .{ }^{12}$ A subsidiary in host country $i$ with a parent in home country $j$ then faces the tax rate $\tau_{i, j}$ on all passive income, where

$$
\tau_{i, j}= \begin{cases}\boldsymbol{\tau}_{j} & \boldsymbol{\tau}_{i}<\alpha \\ \boldsymbol{\tau}_{i} & \boldsymbol{\tau}_{i} \geq \alpha\end{cases}
$$

Consider the full range of possible subsidiary tax rates i.e. the range of host country rates. In the decision of where to locate passive income, the multinational firm faces a tax notch just at the low-tax threshold $\alpha$. Since thresholds are always placed below the home country rate, this notch always features as a downward drop with a magnitude of $\alpha-\boldsymbol{\tau}_{j}<0$. Considering a single home country we depict the tax schedule faced by the multinational firm across possible host rates in Figure 2.

In the current empirical setting we are considering multiple home countries and CFC regimes with different threshold values. While both the absolute size of $\alpha$ as well as the relative size of $\alpha$ compared to $\tau_{j}$ varies across regimes, they all introduce a tax schedule qualitatively illustrated by Figure 2. In the following analysis we utilise the incentives created by this tax schedule to identify the effects of the CFC tax measure.

Our empirical methodology centers on a simple semi-log linearised model described by the

\footnotetext{
${ }^{12}$ Note that the stylised presentation here assumes a low-tax cut-off specified in terms of a statutory flat corporate tax rate in the host country. In reality this is typically not the case: thresholds are more often specified in terms of an effective tax measure taking the actual tax paid by the subsidiary into account. However, the statutory tax rate acts as a proxy for this effective tax rate.
} 
Figure 2:

\section{Illustration of tax on passive income under CFC regime with low-tax threshold}

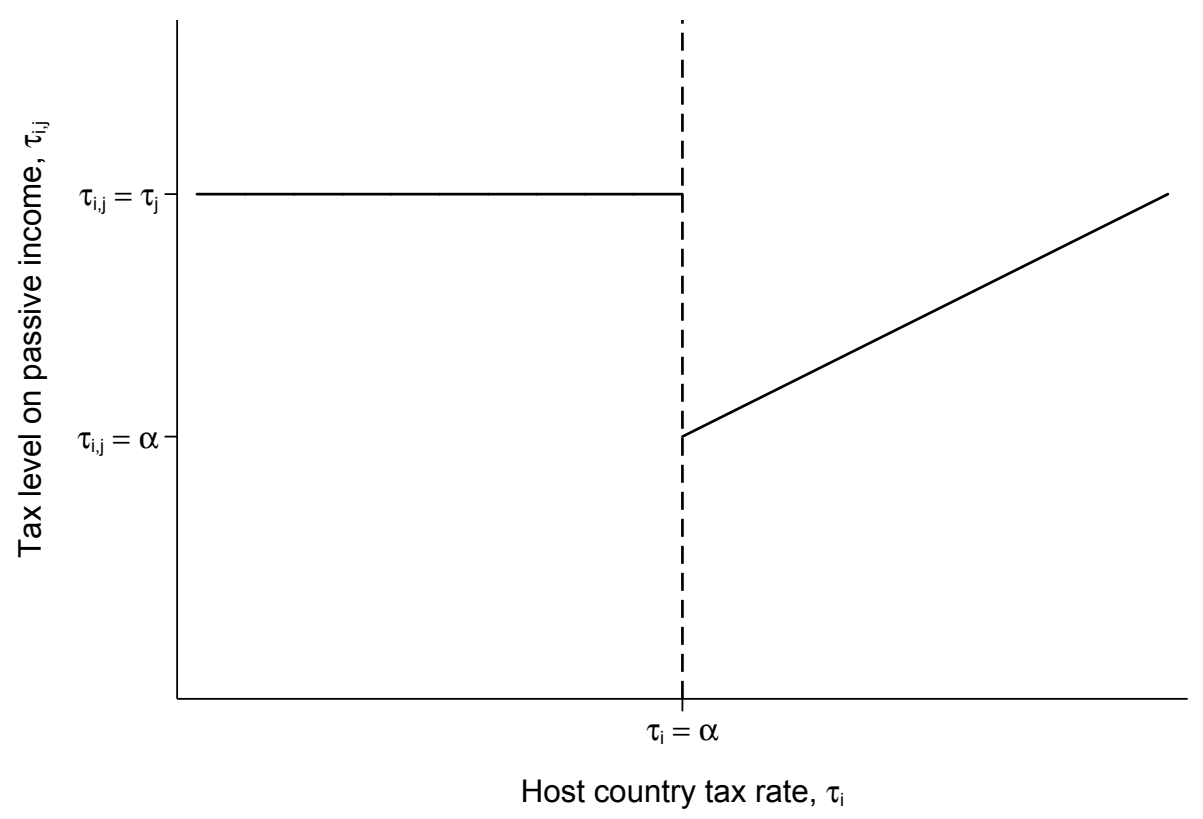

Notes: A stylized illustration of the effective tax rate applicable to the passive income of multinationals as a function of the host country tax rate faced by the subsidiary generating the income. We denote the low-tax threshold $\alpha$, the home country tax rate $\tau_{j}$ and the host country tax rate $\tau_{i}$.

following equation for firm $f$ based in host country $s$, with parent $p$ situated in home country $h$, at time $t$,

$$
\ln (\text { outcome })_{f s p h t}=\alpha+\beta_{1} \mathbb{1}_{[C F C] s h t}+\beta_{4} X_{s t}+\beta_{5} X_{f t}+F E+\varepsilon_{f s p h t}
$$

The CFC targeting indicator variable $\mathbb{1}_{[C F C] \text { sht }}$ is equal to one if host country $s$ has a corporate income tax rate that falls under the low-tax threshold in the CFC legislation of home country $h$ at time $t$. We include host country specific covariates, $X_{s t}$, such as the host country GDP, as well as firm specific covariates, $X_{f t}$, such as the stock of assets of the subsidiary. For the most part we do not include parent or group specific covariates, since main specifications include parent fixed effects. Throughout the analysis we include fixed effects $(F E)$ on various levels to isolate specific sources of variation, including variation from movements across the threshold. 


\section{RESUlts}

We start the analysis by observing a clear pattern in the data consistent with a tax efficient reaction by multinationals to the incentives created by CFC legislation. Figure 3 is based on all subsidiaries in those multinational groups where the parent faces a CFC regime with a specified low-tax threshold. Each subsidiary is sorted according to the statutory tax rate in their respective host country relative to this threshold. Concretely this means that a Canadian subsidiary of a German parent in year 2012 will appear on the graph at a value of 1, since the Canadian statutory tax rate of 26 percent in 2012 is 1 percentage point higher than the German low-tax threshold of 25 percent. Consequently subsidiaries placed to the right of zero are not affected by CFC taxation due to the sufficiently high tax level they face in their respective host country. Conversely, subsidiaries placed to the left are potentially targeted by CFC legislation since they meet the low-tax criterion.

Figure 3 plots in black the overall ratio of financial to operating profit allocated within each separate bin around the low-tax threshold. A striking feature of the overall pattern is a massive jump in the ratio just at the cut-off value. The jump amounts to more than a doubling from around 20 percent to more than 40 percent.

This discontinuity is consistent with a behavioural response to the tax notch created by CFC legislation at the threshold. We illustrate this notch in the tax schedule by including in grey the average tax rate on passive income across subsidiaries in each bin. As explained earlier CFC rules mechanically create this tax notch at the threshold by upholding the home country rate as the effective tax rate on passive income on the entire left hand side. Above the cut-off there is no additional CFC taxation meaning that the host tax rate becomes the effective rate. From a pure tax perspective this notch in the tax schedule creates an incentive to generate passive income in subsidiaries located just above compared to just below the threshold. The discontinuous pattern we observe in the share of financial profit is exactly consistent with these incentives around the cut-off. Furthermore the decreasing pattern on the right side of the threshold indicates tax sensitivity in line with the increasing average statutory tax rate. We do not observe a pronounced pattern to the left of the threshold consistent with the flat tax schedule under CFC rules. This seems to suggest a behavioural pattern within multina- 
Figure 3:

\section{Ratio of financial to operating profit around low-tax threshold}

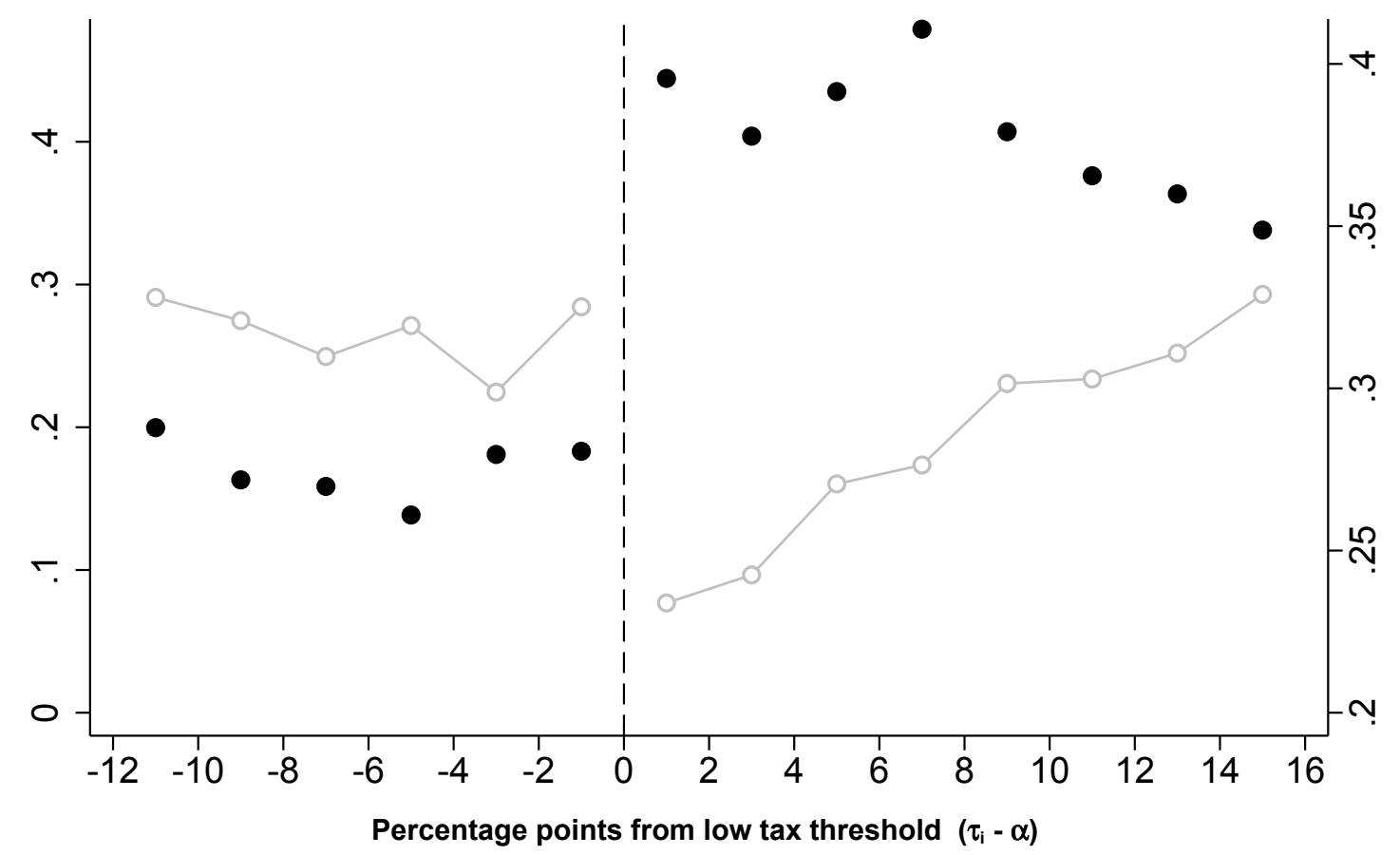

- Ratio of financial to operating profit (within bins) __- - Avg. tax rate on passive income

Notes: Filled circles (left axis) represent the ratio of total financial profit to total operating profit within each 2 percentage point bin. Hollow circles (right axis) represent the average tax rate on passive income faced by the subsidiaries within each bin. Above zero (i.e. above the tax cut-off) this is the average host CTR faced by the subsidiaries in their respective host countries. Below zero (i.e. below the tax cut-off) this is the average home CTR i.e. the corporate tax rate in the country where the parent of the subsidiary is located. We condition on non-negative operating- and financial profit, and observations representing a single-year shift in the CFC indicator are excluded. We use only home-countries with an implemented CFC regime (with a specified tax threshold). All majority owned, foreign subsidiaries are included. We leave out domestic subsidiaries to avoid random fluctuations due to home-bias. We further exclude financial corporations and banks to ensure that operating profit is a meaningful scaling variable. We are not able to extend the figure further to the left due to data coverage. The data availability at such low tax rates is very limited.

tionals focused on generating excess financial income in subsidiaries located exactly outside the grasp of CFC legislation.

Note that we scale by operating profits to account for the plausible relation that larger subsidiaries with more true economic activity, such as for instance commodity sales, need more liquid assets to uphold business. Hereby we attempt to ensure that such size related effects are 
not driving the observed pattern. In Appendix Figures 7 and 8 we show alternative versions of Figure 3, firstly including all negative recordings of financial profit and secondly including only fully owned subsidiaries. Both figures show similar patterns to Figure 3 and both also feature a doubling (or more) of the ratio exactly at the threshold.

Motivated by the observed pattern in Figure 3 we proceed by analysing the potential systematic tendency of multinationals to generate financial income in subsidiaries not targeted by CFC legislation. For this purpose we estimate the simple semi-log linearised model of financial profit introduced earlier. To capture CFC targeting we utilise the variation created by the low-tax threshold. Aside from the host-country corporate tax rate (CTR) we include a CFC targeting indicator variable equal to one if this rate falls under the relevant low-tax threshold. The applicable low-tax cut-off is the threshold specified in the legislation belonging to the home country of the group-parent. Consequently, the variation we are exploiting has both a cross-sectional and a time dimension. The cross-sectional dimension is created by varying cut-off levels and tax rate differentials across host countries, while the time dimension stems from reforms moving subsidiaries across the threshold. The parameter estimate of the targeting variable measures (roughly) the percentage difference in financial profit on a subsidiary level from being targeted by CFC rules compared to being outside the scope of such targeting. Results are given in the first four columns of Table 1.

Disregarding tax incentives there could be other rational reasons for generating a large amount of financial income. A large subsidiary carrying out substantial active economic business such as commodity production and sale will presumably have a need for more liquid assets compared to a smaller and less active subsidiary. Following such logic we set up specifications controlling for this need using firm size as a proxy. We use two different measures of firm size assets $^{13}$ and the number of employees of the subsidiary. The total amount of assets is arguably a better measure of actual firm size, but it also captures some of the variation we are trying to measure since we are unable to exclude financial assets. For this reason we alternatively use the number of employees to account for the magnitude of active economic behaviour.

\footnotetext{
${ }^{13}$ In the asset measure we subtract the amount of intangible assets, since income from intangible assets is also affected by CFC legislation.
} 
Table 1:

\section{CFC rules and the allocation of financial profit within multinationals}

\begin{tabular}{|c|c|c|c|c|c|c|}
\hline & \multicolumn{6}{|c|}{ Outcome: $\ln$ (financial profit) } \\
\hline & (1) & $(2)$ & (3) & (4) & $(5)$ & (6) \\
\hline CFC Indicator & $\begin{array}{l}-1.056^{* * *} \\
(0.212)\end{array}$ & $\begin{array}{l}-0.588^{* * *} \\
(0.105)\end{array}$ & $\begin{array}{l}-0.376^{* * *} \\
(0.096)\end{array}$ & $\begin{array}{l}-0.229^{* * *} \\
(0.081)\end{array}$ & $\begin{array}{l}-0.410^{* * *} \\
(0.095)\end{array}$ & $\begin{array}{l}-0.249^{* * *} \\
(0.079)\end{array}$ \\
\hline CTR & $\begin{array}{r}-0.001 \\
(0.013)\end{array}$ & $\begin{array}{l}-0.053^{* * *} \\
(0.010)\end{array}$ & $\begin{array}{l}-0.038^{* * *} \\
(0.011)\end{array}$ & $\begin{array}{l}-0.044^{* * *} \\
(0.007)\end{array}$ & & \\
\hline $\mathrm{CTR} \times \mathrm{CFC}$ & & & & & $\begin{array}{c}0.024 \\
(0.017)\end{array}$ & $\begin{array}{r}0.015 \\
(0.017)\end{array}$ \\
\hline $\mathrm{CTR} \times(1-\mathrm{CFC})$ & & & & & $\begin{array}{l}-0.043^{* * *} \\
(0.011)\end{array}$ & $\begin{array}{l}-0.048^{* * *} \\
(0.008)\end{array}$ \\
\hline $\ln (\mathrm{GDP})$ & & $\begin{array}{l}0.344^{* * *} \\
(0.041)\end{array}$ & $\begin{array}{l}0.242^{* * *} \\
(0.039)\end{array}$ & $\begin{array}{l}0.155^{* * *} \\
(0.031)\end{array}$ & $\begin{array}{l}0.239^{* * *} \\
(0.040)\end{array}$ & $\begin{array}{l}0.152^{\text {*** }} \\
(0.031)\end{array}$ \\
\hline $\ln ($ GDPPC $)$ & & $\begin{array}{r}0.069 \\
(0.139)\end{array}$ & $\begin{array}{l}0.759^{* * *} \\
(0.146)\end{array}$ & $\begin{array}{r}-0.094 \\
(0.094)\end{array}$ & $\begin{array}{l}0.733^{* * *} \\
(0.141)\end{array}$ & $\begin{array}{r}-0.100 \\
(0.091)\end{array}$ \\
\hline $\ln ($ Corrup) & & $\begin{array}{l}1.372^{* * *} \\
(0.208)\end{array}$ & $\begin{array}{l}1.0166^{* * *} \\
(0.145)\end{array}$ & $\begin{array}{l}0.861^{* * *} \\
(0.120)\end{array}$ & $\begin{array}{l}1.062^{* * *} \\
(0.147)\end{array}$ & $\begin{array}{l}0.899^{* * *} \\
(0.125)\end{array}$ \\
\hline $\ln ($ Distance $)$ & & $\begin{array}{l}-0.135^{* * *} \\
(0.035)\end{array}$ & $\begin{array}{l}-0.062^{* *} \\
(0.029)\end{array}$ & $\begin{array}{c}0.023 \\
(0.021)\end{array}$ & $\begin{array}{l}-0.064^{* *} \\
(0.028)\end{array}$ & $\begin{array}{c}0.022 \\
(0.021)\end{array}$ \\
\hline Dom. Ind & & $\begin{array}{l}0.424^{* * *} \\
(0.071)\end{array}$ & $\begin{array}{l}0.265^{* * *} \\
(0.075)\end{array}$ & $\begin{array}{l}0.247^{* * *} \\
(0.033)\end{array}$ & $\begin{array}{l}0.268^{* * *} \\
(0.075)\end{array}$ & $\begin{array}{l}0.249^{* * *} \\
(0.033)\end{array}$ \\
\hline $\ln (\mathrm{Nr} \mathrm{Emp})$ & & & $\begin{array}{l}0.417^{* * *} \\
(0.021)\end{array}$ & & $\begin{array}{l}0.416^{* * *} \\
(0.021)\end{array}$ & \\
\hline $\ln$ (Other Assets) & & & & $\begin{array}{l}0.935^{* * *} \\
(0.012)\end{array}$ & & $\begin{array}{l}0.934^{* * *} \\
(0.012)\end{array}$ \\
\hline Parent FE & & $\checkmark$ & $\checkmark$ & $\checkmark$ & $\checkmark$ & $\checkmark$ \\
\hline Year FE & & $\checkmark$ & $\checkmark$ & $\checkmark$ & $\checkmark$ & $\checkmark$ \\
\hline Obs (total) & 197034 & 196954 & 114103 & 177843 & 114103 & 177843 \\
\hline Obs (w. CFC=1) & 12140 & 12138 & 8691 & 11247 & 8691 & 11247 \\
\hline Groups & 13970 & 13969 & 11152 & 13521 & 11152 & 13521 \\
\hline$R^{2}(\operatorname{adj})$ & 0.01 & 0.30 & 0.37 & 0.65 & 0.37 & 0.65 \\
\hline
\end{tabular}

In the main specifications we include year fixed effects and parent fixed effects to eliminate between-group differences. Essentially we seek to ensure that measured effects come from allocative choices within each multinational and not from inherent differences across groups. When allocating assets multinationals will plausibly consider factors such as quality of institutions and legal systems, property rights and other similar characteristics of the country hosting 
each subsidiary. To account for such preferences we implement specifications controlling for GDP per capita and corruption using a corruption measure where higher values indicate less corruption. A different dimension of preferences relates to the geographical position of the host country. To address this dimension we include a distance measure controlling for the geographical distance between home and host country, as well as an indicator for domestic subsidiaries to account for the potential home-bias in the investment-preferences of the parent company. As a last host control we include GDP to make sure that the well-established correlation between country size and tax rates does not drive the results. ${ }^{14}$ In Table 1 we focus solely on fully owned subsidiaries to avoid noise associated with joint ownership such as potential influence from partners with conflicting interests.

Across all specifications we obtain a negative and significant estimate of the coefficient for the CFC targeting variable. The negative sign means that subsidiaries affected by the home country CFC regime, generate less financial profit compared to subsidiaries that are not affected by these rules. When including a control for subsidiary size, the coefficient on the CFC targeting variable drops somewhat in magnitude. This could suggest that larger subsidiaries with a larger inherent need for liquid assets are predominantly placed in high-tax environments above the threshold. Focusing on our preferred specification (4) the coefficient estimate suggests that a subsidiary targeted by CFC home country taxation generates 20 percent less financial profit compared to a non-targeted subsidiary within the same group. ${ }^{15}$ As expected we see a strong sensitivity to the corporate tax rate when including controls. Considering our preferred specification, the coefficient on CTR reflects a semi-elasticity of financial profit of 4.4 with respect to the host country corporate tax rate. Looking at the included size controls, larger subsidiaries generate more financial profit as we intuitively argued. As results are similar for both size controls, we only use the asset measure moving forward, as this measure has the largest coverage.

\footnotetext{
${ }^{14}$ To test for robustness of these results we included various alternative control variables with a potential effect on the level of financial income of foreign subsidiaries. Among these are for instance contiguity of homehost countries or a common home-host language. These alternative controls do not change any of the results in any qualitative manner.

${ }^{15}$ Using the formula $\exp (c)-1$ ( $c$ being the estimated coefficient) suggested in (Halvorsen \& Palmquist, 1980) for interpretation of coefficients on dummy variables in logarithmic specifications.
} 
In the last two columns of Table 1 we investigate a point initially mentioned in Ruf \& Weichenrieder (2012). Since CFC legislation imposes the home rate as the effective tax rate below the threshold, we should only observe sensitivity to the host country tax rate above the cut-off. We test whether this is in fact the case by including interaction terms between our CFC targeting dummy and the host corporate tax rate in the main specifications. In both specifications we indeed observe the standard negative sensitivity above the cut-off, but not below. The coefficient below the threshold is even positive, however not significant. To obtain comparability of the parameter estimates on the CFC targeting variable across specifications, we center the corporate tax rate around 18 percent when including the interaction terms in columns (5) and (6). The chosen centre value represents the average cut-off level across home countries and sample years, and estimates should hence be interpreted as the effect of CFC targeting on a company facing a host corporate tax rate of 18 percent.

In the Appendix Table 5 we run each specification from Table 1 with fixed effects on the interaction level instead i.e. with parent $\times$ year fixed effects. Hereby we exclude variation in CFC targeting coming from the time-dimension and identify only from variation within each multinational group in a single year. Further, we estimate each specification using all majority owned subsidiaries. Results are presented in the Appendix Table 6. The estimates from both tables are very similar to the main results given in Table 1, both in terms of magnitudes and significance levels.

As we highlighted with a brief remark above, the identifying variation used in the analysis up to this point contains both a cross-sectional and a time dimension. In the cross-section subsidiaries of a UK parent hosted in Bulgaria are compared to subsidiaries of the same UK parent hosted in Finland as an example. Since the Finnish tax level is above the British low-tax threshold, while the Bulgarian is below, we have variation in the applicability of the British CFC rules. In the time dimension we exploit tax reforms in home and host countries moving subsidiaries across the cut-off in one or multiple home countries. In 2012 Finland implemented a tax reform lowering the corporate tax rate whereby Finland moved from above to below the German low-tax threshold. This reform hence affected the CFC treatment of Finnish subsidiaries with German parents, while leaving the treatment of Finnish subsidiaries with British parents unchanged. In 2008 Spain introduced a tax reform lowering the Spanish 
corporate tax rate. A feature of the CFC legislation in Spain is a low-tax threshold defined as a percentage of the Spanish corporate tax level. Consequently the 2008 tax reform simultaneously lowered the CFC tax cut-off, and thereby moved Russian subsidiaries from below the Spanish cut-off to above, despite a constant statutory corporate tax rate of 24 percent in Russia in these years. A final type of time variation is exemplified by the Japanese reform in 2010 where Japan lowered the CFC tax threshold from an absolute value of 25 to a rate of 20 percent. This shift changed the status of subsidiaries located in the Republic of Korea from CFC targeted to non-targeted.

To alleviate concerns that results could be driven by unobservable characteristics of host countries, we exploit the richness of variation in the data and focus solely on the time dimension. The isolation is achieved through specifications including either parent $\times$ host-country fixed effects or a full set of subsidiary fixed effects. Importantly both these sets embed host $\times$ home-country fixed effects. Hence we eliminate time invariant country pair differences and obtain identification directly from the change in financial profit occurring when subsidiaries cross the tax threshold due to a tax reform or a direct reform of the relevant CFC legislation. ${ }^{16}$ Results are presented in Table 2.

In the first three columns of Table 2 , we present specifications including parent $\times$ host-country fixed effects. These fixed effects remove all differences both across groups and across host countries within groups causing only within host and group variation to remain. In column (1) we further include year fixed effects to control for the general time trend among all subsidiaries. In column (2) we include host country specific time trends and in column (3) we include both host specific and home country specific time trends. The resulting coefficients on the CFC targeting variable are all negative, of very similar magnitude and significant at the 1 percent level. Using the estimate from column 3 a subsidiary moving across the threshold and into potential CFC taxation experiences a 20 percent drop in financial profit on average. ${ }^{17}$

\footnotetext{
${ }^{16}$ When focusing exclusively on variation in the time dimension we impose a restriction of at least three entities within each group. This restriction is introduced to ensure that parent corporations have the opportunity to shift income between at least two foreign locations and hence that a reaction to a reform is plausible without a very long time lag.

${ }^{17}$ Note here that we assume effects of crossing the threshold from above and crossing the threshold from below to be identical, since we are pooling both types of variation in the estimation. The result could hence
} 
In the final three columns we introduce a full set of subsidiary fixed effects, and hence identify only from variation within the single subsidiary over time. In column (4) we again include year fixed effects. Conceptually this specification identifies the effect of CFC targeting from the variation created when a subsidiary is moved across the threshold by a reform, using all other subsidiaries that do not change status as controls to account for other potential policyinfluences or shocks. In column (5) we include host country specific time fixed effects. This specification again exploits variation within a subsidiary crossing the threshold, but instead of using all other unaffected subsidiaries as controls, it only uses subsidiaries within the same host country that are not affected by the reform due to differences in parent country. In column (6) we take this approach a step further by using both host specific time trends and home specific time trends. In essence, this constitutes an approach using two different control groups to account for two distinct sources of confounding influence. As in column (5) unaffected subsidiaries within the same host country are used to control for unrelated shocks affecting the specific host market. However, we further use a second control group consisting of all subsidiaries with the same home country, to control for the confounding influence of other unrelated policies or shocks affecting foreign investments of a specific parent country. Across these three specifications, we again obtain negative and significant estimates of the CFC targeting parameter. The magnitude of the estimates is very similar across specifications, however slightly smaller compared to the first three columns. The estimate from column (6) using both a within-host and a within-home control group, indicates a 14 percent drop in financial profit upon being moved below the threshold.

As of now we have analysed the implications of CFC legislation for the allocation of passive profit using different dimensions of variation. To supplement these results we now turn to an analysis of the ratio of financial to operating profit within each subsidiary. Because CFC legislation targets passive income and not active income such as income from production sale, subsidiaries below the CFC threshold can still benefit from a low host tax rate on their active income. $^{18}$ Consequently, CFC targeting induces a discrepancy between the relative gains also be formulated as a 20 percent increase in financial profit upon moving above the threshold.

${ }^{18}$ This is the case for almost all CFC regimes, however examples do exist of legislation that targets both dimensions - for instance the CFC rules in Brazil. 
Table 2:

\section{CFC rules and the allocation of financial profit within multinationals}

\begin{tabular}{|c|c|c|c|c|c|c|}
\hline & \multicolumn{6}{|c|}{ Outcome: $\ln$ (financial profit) } \\
\hline & $(1)$ & $(2)$ & $(3)$ & $(4)$ & $(5)$ & $(6)$ \\
\hline CFC Indicator & $\begin{array}{c}-0.2380^{* * *} \\
(0.0700)\end{array}$ & $\begin{array}{c}-0.2144^{* * *} \\
(0.0563)\end{array}$ & $\begin{array}{c}-0.2167^{* * *} \\
(0.0602)\end{array}$ & $\begin{array}{c}-0.1663^{* *} \\
(0.0804)\end{array}$ & $\begin{array}{c}-0.1310^{* *} \\
(0.0596)\end{array}$ & $\begin{array}{c}-0.1525^{* *} \\
(0.0595)\end{array}$ \\
\hline CTR & $\begin{array}{l}0.0096 \\
(0.0088)\end{array}$ & - & - & $\begin{array}{c}0.0141 \\
(0.0110)\end{array}$ & - & - \\
\hline $\ln (\mathrm{GDP})$ & $\begin{array}{r}1.2170 \\
(1.0255)\end{array}$ & - & - & $\begin{array}{r}1.7174 \\
(1.2535)\end{array}$ & - & - \\
\hline $\ln (\mathrm{GDPPC})$ & $\begin{array}{r}-0.3123 \\
(1.0073)\end{array}$ & - & - & $\begin{array}{r}-0.3795 \\
(1.2648)\end{array}$ & - & - \\
\hline $\ln ($ Corrup) & $\begin{array}{c}0.3004 \\
(0.3566)\end{array}$ & - & - & $\begin{array}{r}0.3300 \\
(0.4139)\end{array}$ & - & - \\
\hline $\ln ($ Distance $)$ & - & - & - & - & - & - \\
\hline Dom. Ind & - & - & - & - & - & - \\
\hline $\ln$ (Other Assets) & $\begin{array}{l}0.9211^{* * *} \\
(0.0143)\end{array}$ & $\begin{array}{l}0.9220^{* * *} \\
(0.0143)\end{array}$ & $\begin{array}{l}0.9217^{* * *} \\
(0.0144)\end{array}$ & $\begin{array}{l}0.7161^{* * *} \\
(0.0184)\end{array}$ & $\begin{array}{l}0.6992^{* * *} \\
(0.0208)\end{array}$ & $\begin{array}{l}0.6983^{* * *} \\
(0.0211)\end{array}$ \\
\hline Subsidiary FE & & & & $\checkmark$ & $\checkmark$ & $\checkmark$ \\
\hline Parent $\times$ Host FE & $\checkmark$ & $\checkmark$ & $\checkmark$ & - & - & - \\
\hline Year FE & $\checkmark$ & - & - & $\checkmark$ & - & - \\
\hline Year $\times$ Host FE & & $\checkmark$ & $\checkmark$ & & $\checkmark$ & $\checkmark$ \\
\hline Year $\times$ Home FE & & & $\checkmark$ & & & $\checkmark$ \\
\hline Obs (total) & 168964 & 169007 & 168747 & 168964 & 169007 & 168747 \\
\hline Obs (w. $\mathrm{CFC}=1$ ) & 8891 & 8886 & 8834 & 8891 & 8886 & 8834 \\
\hline$R^{2}(\operatorname{adj})$ & 0.68 & 0.68 & 0.68 & 0.81 & 0.82 & 0.82 \\
\hline
\end{tabular}

Notes: The unit of observation is subsidiaries of parents located in CFC countries with a specified low-tax threshold while the dependent variable is the natural logarithm of financial profit. Observations representing a single-year shift in the CFC indicator, are excluded in all specifications - this restriction never represents more than 200 excluded observations. We include all groups consisting of at least 3 entities. All specifications include only fully owned subsidiaries. In columns (3) and (6) we drop observations in home $\times$ year or host $\times$ year groups consisting of less than 8 observations for computational feasibility. This affects less than 300 observations - if we instead group these observations by year and include dummy variables for each group, computation is still feasible and results do not change. Standard errors in parentheses, clustered at the country-year level. $* * * \mathrm{p}<0.01, * * \mathrm{p}<0.05, *$ $\mathrm{p}<0.1$

accruing to a subsidiary with a high ratio of financial to operating profit versus a lower ratio company when choosing a low-tax location. Under CFC targeting very high ratio companies will potentially be liable for additional home country taxation on a large fraction of income, and correspondingly the potential benefit of enjoying a low tax rate on active income is small. This relation will all else equal be less severe for a lower ratio company. Such logic firstly suggests that CFC targeted low-tax environments should all else equal host less subsidiaries 
with large ratios of passive to active profit, compared to non-targeted host countries. Second, the absolute effect of CFC targeting on the probability of having a considerable ratio of passive to active profit should increase for increasing ratios.

We calculate for each subsidiary the ratio of financial to operating profit, conditioning only on operating profit being positive. This ratio can naturally be negative but it can also potentially be much larger than 1 since financial profit does not act as a part of operating profit. Operating profit in contrast reflects actual sales and other entries traditionally viewed as active economic business. We set up a simple linear probability model where the left hand side is equal to a binary indicator for this ratio being above some specified threshold value. The right hand side variables are the same as previously introduced, including the CFC targeting indicator as the variable of primary interest.

In the main specification we do not include a subsidiary size control on the right hand side, since we scale by operating profit and hence take account of the concern that larger firms with more active business have a larger need for liquid assets. ${ }^{19}$

Figure 4 plots the coefficient estimate of the CFC targeting variable in the described model using different thresholds for the LHS indicator. To create a clear picture of the magnitudes of these effects, each estimate is expressed as a fraction of the baseline probability - the coefficient estimate is scaled by the fraction of positives of the LHS variable. Consequently, the first point represents the effect of CFC taxation on the probability of having a ratio of financial to operating profit above 0.1 , as a fraction of the overall sample probability of having a ratio above 0.1 . Since the baseline probability is an estimated statistic we introduce additional uncertainty when scaling by this parameter. Therefore we use a bootstrapping approach with clustered resampling at the group level when calculating standard errors. A version of the figure with unscaled parameter estimates and traditionally calculated confidence bands is given in the Appendix Figure 10.

All threshold choices result in a negative parameter estimate, and for all values of 30 percent or more we get statistical significance at the 5 percent level or lower. This consistent result indicates that CFC targeting has a significantly negative effect on the probability of having a

\footnotetext{
${ }^{19}$ To test robustness we replicate the analysis with total assets excluding intangible assets as size control on the RHS. See the Appendix Figure 9 for an analogous counterpart to Figure 4.
} 
Figure 4:

\section{Linear probability model for financial profit ratio being above specified thresholds - Coefficient estimates of CFC targeting indicator}

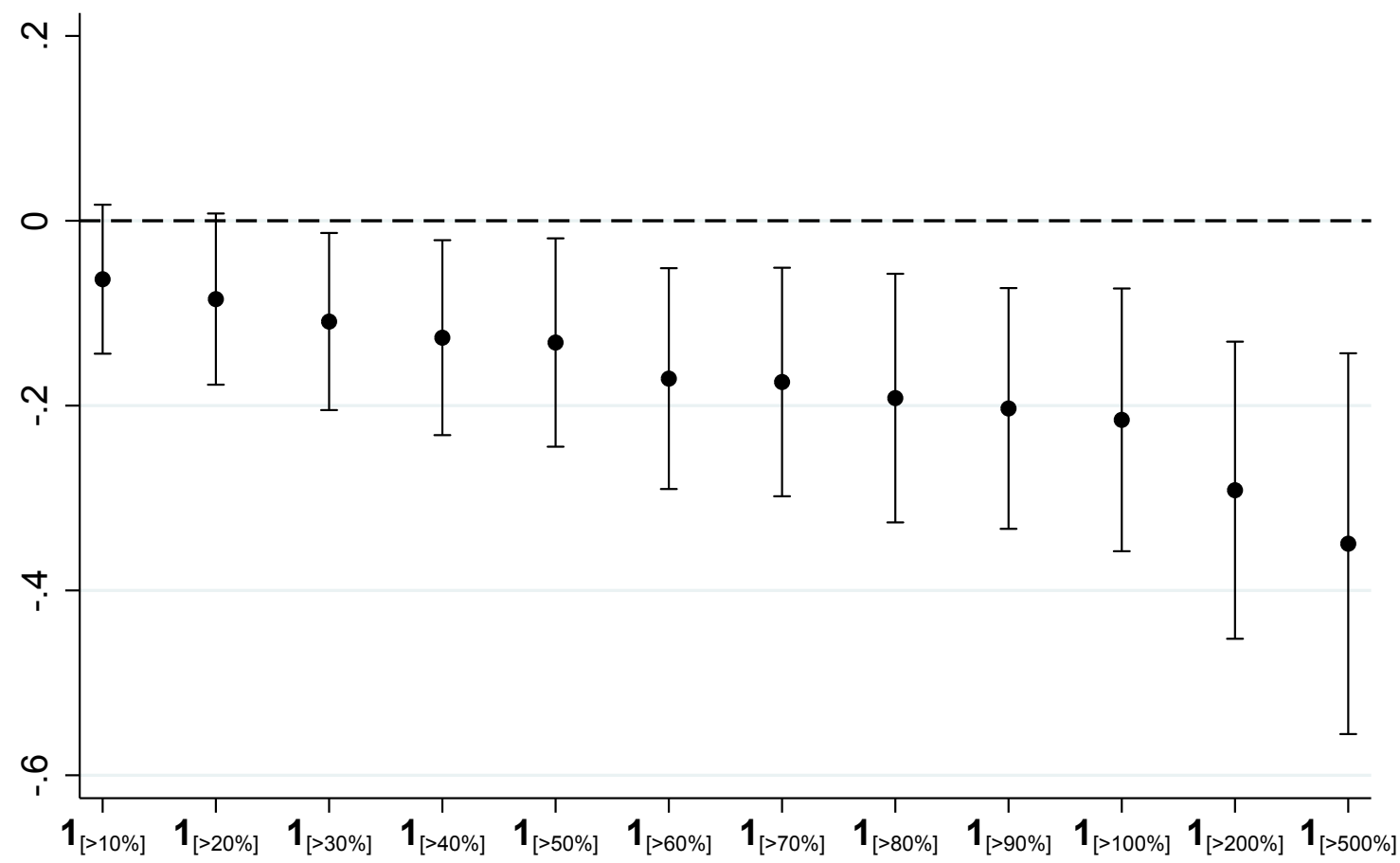

Notes: The LHS in each estimation is an indicator variable equal to one if the ratio of financial to operating profit is above the specified threshold indicated on the x-axis. Circles represent estimates of the coefficient on the CFC targeting indicator scaled by an estimate of the fraction of positives of the LHS variable, i.e. the CFC indicator estimate as a fraction of the baseline probability. Vertical capped lines represent $95 \%$ confidence intervals. Included host controls are: CTR, $\log ($ GDP), $\log ($ GDP PC), $\log$ (Corruption), $\log$ (Distance) and an indicator for being a domestic subsidiary. We do not include a control on the RHS for subsidiary size since the LHS variable is scaled by total operating profit. All estimations include year FE and Parent FE. We condition on positive operating profit. Observations representing a single shift in the CFC indicator are excluded - this restriction never represents more than 200 excluded observations. We calculate standard errors using a bootstrap approach with clustered resampling at the group (parent) level and 1000 replications for each calculation. We use only home-countries with an implemented CFC regime, and only fully owned subsidiaries are included. Each estimation is based on a total of 310.988 observations, and a total of 19.209 multinational groups.

high level of financial compared to operating profit or in more general terms a high ratio of passive to active profit.

Also in line with described expectations, we observe a monotonically decreasing pattern of the estimates suggesting that the relative magnitude of the effect of potential CFC taxation is 
larger when we consider the probability of having very large ratios compared to more moderate ones. In other words, the absolute effect is increasing for increasing ratios. A last important takeaway from Figure 4 relates to the magnitude of the estimates. The effect of CFC targeting on the probability of having financial profit more than half the size of operating profit is a reduction equal to 13 percent of the baseline probability. The size of the effect of targeting on the probability of having more than twice as much financial as operating profit is close to 30 percent of the baseline. ${ }^{20}$

\section{SHIFTING BEHAVIOUR AND REVENUE CONSEQUENCES}

Entering potential CFC taxation leads to a sizeable drop in financial profit within a foreign subsidiary of a multinational firm. This overall conclusion raises the question of whether the observed drop arises from a genuine downsizing or from a redirection of profits. In other words, does the missing profit reappear within the multinational group and if so then where? Mapping the underlying behavioural patterns within the multinational firm is essential for the ability to evaluate consequences for the magnitude and distribution of global corporate tax revenues - a question of high importance to policy makers.

To investigate group dynamics we introduce the concept of group-exposure to the CFC measure into a framework very similar to the one presented earlier. By group-exposure we mean something measuring the degree to which a group is affected by CFC legislation. One way to assess this is to consider the number of subsidiaries within a group placed in environments below the relevant tax threshold. We use two measures of group-exposure: first, the total number of group-members (aside from the considered subsidiary itself) falling below the tax threshold and second the fraction of subsidiaries within a group placed below the threshold. Table 3 presents estimation results of specifications very similar to those implemented above, but now further including one of these measures. In the first three columns, the number of CFC targeted subsidiaries is used to measure group-exposure. For each firm observation, the exposure variable contains the number of other group members that fall under the CFC low-tax threshold at that given point in time. From column (1) we see that this variable has a

\footnotetext{
${ }^{20}$ Note that the analysis above does not rely on a logarithmic transformation of the outcome variable, and hence includes both zero- and negative recordings of financial profit.
} 
significant positive effect. This result implies that other firms within the same group generate more financial profit when an additional CFC targeted subsidiary enters. A control for the total number of subsidiaries in each group is included to make sure the effect is not a scale effect related to group size, but indeed a within-group compositional effect. The magnitude of the estimate suggests that an additional CFC targeted subsidiary within a group raises the financial profit of other group members by 0.1 percent.

In column (2) we interact the exposure variable with our CFC targeting indicator to investigate whether this gain accrues to all other members or only those not targeted by CFC legislation themselves. Results indeed indicate the latter to be the case. Considering only members above the threshold, measured effects are highly significant, positive and larger than the overall effect presented in column (1). This is however not the case for members who are CFC targeted themselves, where effects even appear to be negative. A negative effect on targeted subsidiaries could reflect a greater return to the development of new profit shifting ideas or well-functioning shifting mechanisms when exposure is greater. Such new initiatives, brought on by larger exposure, might plausibly affect all targeted subsidiaries, since it is now generally easier to shift profits within the group. Note however that the significance level of this estimate never exceeds a marginal significance at the 10 percent level.

In column (3) we additionally include an interaction with the domestic subsidiary indicator variable. The objective of this specification is to explore whether the positive effect for non-targeted subsidiaries also applies to domestic firms placed in the home country of the group-parent. Note that these companies by construction of the rules always appear above the low-tax threshold. The result of this interaction suggests that domestic subsidiaries experience the same increase in financial profit as other subsidiaries above the threshold, when group-exposure increases. The magnitude of the effect is very similar for domestic and foreign non-targeted companies - an additional targeted group member raises financial profit within each of these firms by around 0.15 percent.

In the last three columns of table 3 we replicate the specifications of the first three columns using a different exposure measure. Instead of using the total number of targeted subsidiaries within a group, we use the fraction of subsidiaries that lie below the low-tax threshold. Perhaps it is not only the number of subsidiaries below the threshold that matters, but instead 
the relative number compared to the number above. In other words - how large a portion of the group is affected. Using this second measure produces results completely in line with the results obtained with the first measure. An increase of 10 percentage points in the fraction of targeted subsidiaries within a group raises the financial profit of both domestic subsidiaries within the group and other subsidiaries above the threshold by about 3.5 percent.

The overall patterns described in this section are consistent with shifting behaviour within multinationals in the direction from targeted to non-targeted subsidiaries. The results seem to document a behavioural pattern where multinationals extract financial profit from subsidiaries falling under the threshold, and place this additional profit within members placed above. The consequence of such behaviour is a movement of profit up along the corporate income tax range into higher tax environments, whereby more global corporate tax revenue emerges. The patterns also suggest that part of this additional tax revenue accrues to the home country administering the $\mathrm{CFC}$ rules, since domestic subsidiaries attract more financial profit when other foreign group-members are targeted.

\section{The EXTEnsive MARGIN - CHOICE OF SUbSidiaRY LOCATION}

The analysis so far has focused on the allocation of income within multinationals given a fixed corporate structure. Such allocative reactions represent an intensive margin of response in the sense that subsidiary holdings react to active CFC legislation. However, the underlying multinational firm structure might also be responsive to this type of tax rule. On the extensive margin, multinationals could react by adjusting the location of new subsidiaries or by other means changing their international patterns of location.

We proceed by investigating this margin of response. The dataset contains a recording of the date of incorporation for each subsidiary making it possible to identify subsidiaries incorporated during the sample period from 2003 to 2013. Considering the full dataset, this produces 152.304 new fully owned incorporations located in 103 different host countries. Multinationals from the $18 \mathrm{CFC}$ countries with a low-tax cut-off account for 69.057 of these new incorporations, while multinationals from countries without a CFC regime account for 69.516. Throughout the analysis, we focus on the subset of new incorporations that are fully owned and placed in foreign countries to avoid noise from home bias driving the results above the 
Table 3:

\section{CFC rules and the allocation of financial profit within multinationals}

\begin{tabular}{|c|c|c|c|c|c|c|}
\hline & \multicolumn{3}{|c|}{$\begin{array}{l}\text { Group exposure: } \\
\text { Number of targeted subs }\end{array}$} & \multicolumn{3}{|c|}{$\begin{array}{l}\text { Group exposure: } \\
\text { Fraction of targeted subs }\end{array}$} \\
\hline & $(1)$ & $(2)$ & $(3)$ & $(4)$ & $(5)$ & (6) \\
\hline CFC Indicator & $\begin{array}{l}-0.2647^{* * *} \\
(0.0860)\end{array}$ & $\begin{array}{l}-0.1832^{* * *} \\
(0.0679)\end{array}$ & $\begin{array}{l}-0.1825^{* * *} \\
(0.0680)\end{array}$ & $\begin{array}{l}-0.2778^{* * *} \\
(0.0794)\end{array}$ & $\begin{array}{l}-0.2268^{* * *} \\
(0.0820)\end{array}$ & $\begin{array}{l}-0.2279^{* * *} \\
(0.0821)\end{array}$ \\
\hline CTR & $\begin{array}{r}0.0033 \\
(0.0070)\end{array}$ & $\begin{array}{r}0.0037 \\
(0.0071)\end{array}$ & $\begin{array}{r}0.0037 \\
(0.0071)\end{array}$ & $\begin{array}{r}0.0035 \\
(0.0070)\end{array}$ & $\begin{array}{r}0.0037 \\
(0.0070)\end{array}$ & $\begin{array}{l}0.0037 \\
(0.0070)\end{array}$ \\
\hline Group exposure & $\begin{array}{l}0.0009^{* * *} \\
(0.0003)\end{array}$ & & & $\begin{array}{l}0.2431^{* * *} \\
(0.0796)\end{array}$ & & \\
\hline Group exp. $\times$ CFC & & $\begin{array}{l}-0.0010^{*} \\
(0.0005)\end{array}$ & $\begin{array}{l}-0.0010^{*} \\
(0.0005)\end{array}$ & & $\begin{array}{r}-0.0164 \\
(0.1691)\end{array}$ & $\begin{array}{r}-0.0165 \\
(0.1691)\end{array}$ \\
\hline Group exp. $\times(1-\mathrm{CFC})$ & & $\begin{array}{l}0.0014^{* * *} \\
(0.0004)\end{array}$ & & & $\begin{array}{l}0.3514^{* * *} \\
(0.0794)\end{array}$ & \\
\hline Group exp. $\times(1-\mathrm{CFC}) \times$ D.Ind & & & $\begin{array}{l}0.0013^{* * *} \\
(0.0005)\end{array}$ & & & $\begin{array}{l}0.3765^{* * *} \\
(0.0976)\end{array}$ \\
\hline Group exp. $\times(1-\mathrm{CFC}) \times(1-$ D.Ind $)$ & & & $\begin{array}{l}0.0015^{* * *} \\
(0.0004)\end{array}$ & & & $\begin{array}{l}0.3052^{* *} \\
(0.1440)\end{array}$ \\
\hline Group size & $\begin{array}{r}-0.0000 \\
(0.0000)\end{array}$ & $\begin{array}{r}-0.0001 \\
(0.0000)\end{array}$ & $\begin{array}{r}-0.0001 \\
(0.0000)\end{array}$ & $\begin{array}{l}0.0000 \\
(0.0000)\end{array}$ & $\begin{array}{l}0.0000 \\
(0.0000)\end{array}$ & $\begin{array}{l}0.0000 \\
(0.0000)\end{array}$ \\
\hline $\ln (\mathrm{GDP})$ & $\begin{array}{l}1.5600 * \\
(0.8746)\end{array}$ & $\begin{array}{l}1.5161 \\
(0.8749)\end{array}$ & $\begin{array}{l}1.5154^{*} \\
(0.8751)\end{array}$ & $\begin{array}{l}1.5820^{*} \\
(0.8740)\end{array}$ & $\begin{array}{l}1.5653^{*} \\
(0.8737)\end{array}$ & $\begin{array}{l}1.5711^{*} \\
(0.8739)\end{array}$ \\
\hline $\ln (\mathrm{GDPPC})$ & $\begin{array}{r}-0.9225 \\
(0.8374)\end{array}$ & $\begin{array}{r}-0.8997 \\
(0.8291)\end{array}$ & $\begin{array}{r}-0.8992 \\
(0.8291)\end{array}$ & $\begin{array}{r}-0.9509 \\
(0.8344)\end{array}$ & $\begin{array}{r}-0.9255 \\
(0.8343)\end{array}$ & $\begin{array}{r}-0.9304 \\
(0.8353)\end{array}$ \\
\hline $\ln$ (Corrup) & $\begin{array}{c}0.5422 \\
(0.3658)\end{array}$ & $\begin{array}{r}0.5370 \\
(0.3602)\end{array}$ & $\begin{array}{r}0.5366 \\
(0.3603)\end{array}$ & $\begin{array}{r}0.5430 \\
(0.3629)\end{array}$ & $\begin{array}{r}0.5345 \\
(0.3643)\end{array}$ & $\begin{array}{c}0.5337 \\
(0.3644)\end{array}$ \\
\hline $\ln ($ Distance $)$ & - & - & - & - & - & - \\
\hline Dom. Ind & - & - & - & - & - & - \\
\hline $\ln$ (Other Assets) & $\begin{array}{l}0.9344^{* * *} \\
(0.0107)\end{array}$ & $\begin{array}{l}0.9344^{* * *} \\
(0.0107)\end{array}$ & $\begin{array}{l}0.9344^{* * *} \\
(0.0107)\end{array}$ & $\begin{array}{l}0.9344^{* * *} \\
(0.0107)\end{array}$ & $\begin{array}{l}0.9341 \text { *** } \\
(0.0108)\end{array}$ & $\begin{array}{l}0.9341^{* * *} \\
(0.0107)\end{array}$ \\
\hline Host $\times$ Home FE & $\checkmark$ & $\checkmark$ & $\checkmark$ & $\checkmark$ & $\checkmark$ & $\checkmark$ \\
\hline Year FE & $\checkmark$ & $\checkmark$ & $\checkmark$ & $\checkmark$ & $\checkmark$ & $\checkmark$ \\
\hline Obs (total) & 168964 & 168964 & 168964 & 168964 & 168964 & 168964 \\
\hline Obs (w. $\mathrm{CFC}=1$ ) & 8891 & 8891 & 8891 & 8891 & 8891 & 8891 \\
\hline$R^{2}(\operatorname{adj})$ & 0.61 & 0.61 & 0.61 & 0.61 & 0.61 & 0.61 \\
\hline
\end{tabular}

Notes: The unit of observation is subsidiaries of parents located in CFC countries with a specified low-tax threshold while the dependent variable is the natural logarithm of financial profit. Observations representing a single-year shift in the CFC indicator, are excluded in all specifications - this restriction never represents more than 200 excluded observations. We include all groups consisting of at least 3 entities. All specifications include only fully owned subsidiaries. In column (2)-(3) and (5)-(6) the CFC exposure variable is centered around the sample mean, 22 and 0.07 respectively. Standard errors in parentheses, clustered at the country-year level. ${ }^{* * *} \mathrm{p}<0.01,{ }^{* *} \mathrm{p}<0.05,{ }^{*} \mathrm{p}<0.1$

threshold.

Analysing the discrete location choice is complicated by the existence of unobservable market conditions rendering some locations attractive for non-tax related reasons. To overcome this issue we look at the relative incorporation pattern of CFC affected groups relative to multi- 
national groups from non-CFC countries. Hereby we implicitly assume that multinationals from countries with no $\mathrm{CFC}$ legislation react to the same underlying market conditions in each potential host country. In other words, a German and an Austrian multinational firm react to the same non-tax related market conditions on the Swiss market when considering an investment in Switzerland. This could for instance be a well-functioning financial market, an effective banking sector or simply an increase in demand for some product or service.

For each home-host-year combination, we compute the probability for the home country of setting up a new subsidiary in that particular host country. This probability is calculated as the number of incorporations within that host-year pair divided by the total number of incorporations in the year in question. The underlying question answered by these probabilities is roughly as follows: given that a German multinational firm wants to set up a new subsidiary in 2010, what is the probability that this new subsidiary will be Swiss. This specific probability is calculated as the fraction of new incorporations made by German multinationals in 2010 that were placed in Switzerland.

We calculate these yearly incorporation probabilities separately for each of the 18 home countries with CFC rules containing a low-tax threshold as well as for the collected group of countries with no CFC legislation. ${ }^{21}$ By subtracting the probabilities calculated for the latter group from the corresponding probabilities for each CFC country, we generate a set of incorporation probability differences. These differences show how the incorporation pattern of multinationals from each CFC country in the sample varies from the pattern of new incorporations made by groups that are unaffected by CFC legislation. If each CFC country has an incorporation pattern identical to the pattern observed for non-CFC countries then all these differences will be zero. Conversely, a positive value indicates that the respective CFC country has an over-probability of incorporation while a negative value signifies an under-probability. In Figure 5 panel (a) we sort the differences in incorporation probabilities relative to the low-tax threshold and sum within 2 percentage point bins. The figure shows a clear pattern

\footnotetext{
${ }^{21}$ Figure 12 in the appendix shows the distribution of incorporations across home countries apart from the 18 countries with CFC legislation and a low-tax threshold. Note that a rather large fraction if these observations stem from tax haven countries. In the main analysis we exclude these observations, however we validate that results are qualitatively identical when including these groups.
} 
of positive probability mass above the cut-off and negative mass below. This distribution suggests that CFC affected multinational groups have a higher probability of placing new subsidiaries in host countries placed above the relevant low-tax threshold and a lower probability of placing new incorporations below the cut-off compared to non-affected multinational groups. In the presented figure the non-affected control group contains multinationals from all countries with no CFC legislation that does not qualify as a tax haven. ${ }^{22}$ Including the set of tax haven countries as well as the four countries in the sample which have a CFC regime, but are unaffected by a tax threshold results in a very similar picture displaying the same patterns (see the Appendix Figure 13).

Figure 5 panel (a) is based on calculated distributions of probability differences across the corporate tax range for each of the 18 included $\mathrm{CFC}$ regime countries. The coverage on each CFC country varies and hence some of the distributions are calculated on a basis of few observations. Considering only the mentioned 18 CFC countries, Figure 11 in the Appendix presents histograms showing the number of new incorporations for each home country. To acknowledge that some distributions have substantially more precision, and assert that the observed pattern is not driven by random noise in the least precise calculations, we introduce weights. Each observation is weighted by the share of total new incorporations in the same year which are attributable to the home country in question. The incorporation probability difference for German multinationals in Switzerland in 2010 is consequently weighted by the German share of new incorporations made by CFC affected groups in 2010. By construction weights sum to one across the 18 home countries within years, and the largest weights are put on the probability distributions relying on the largest amount of observations. Introducing these weights does not change the pattern of positive mass above the cut-off and negative mass below as is shown in Figure 14 in the Appendix.

To assess the statistical significance of these differences we incorporate the calculated distributions in a regression framework. The incorporation probability differences are regressed on a full set of dummies indicating placement in 2 percentage point bins relative to the relevant low-tax threshold. We include year fixed effects and use the $[-2,0)$ bin as the base, such that all coefficients represent deviations relative to a placement just below the threshold. Figure 5

\footnotetext{
${ }^{22}$ To identify tax haven countries we use the list of countries provided in (Hines, 2010) Table 1.
} 
Figure 5:

\section{Differences in incorporation probabilities (CFC groups vs. non-CFC groups)}

(a)

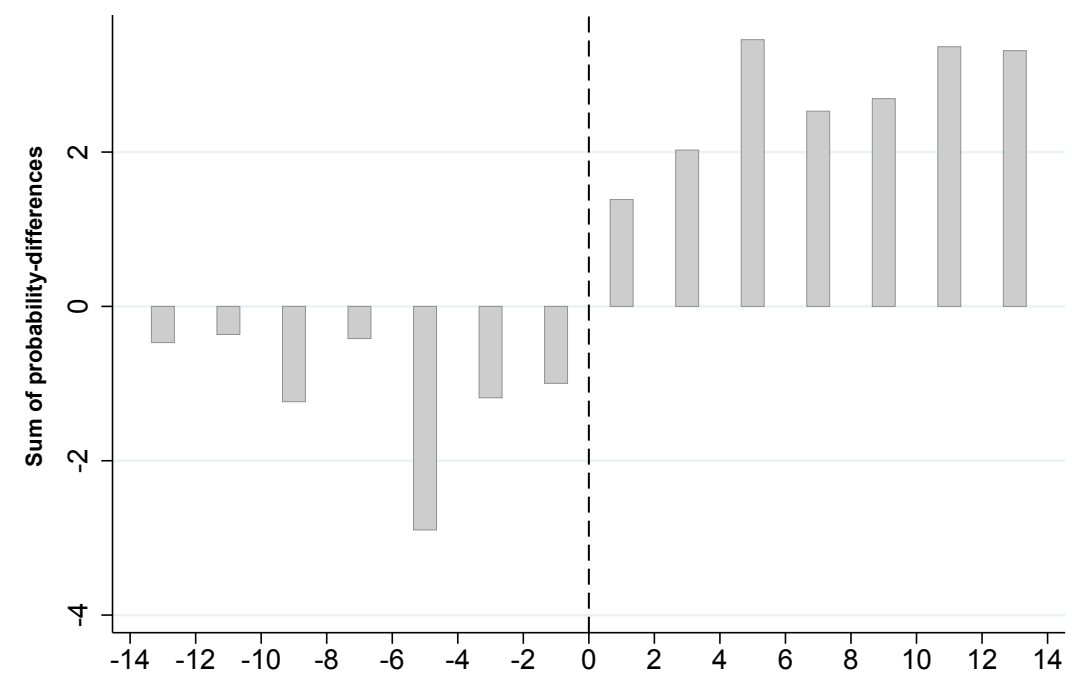

(b)

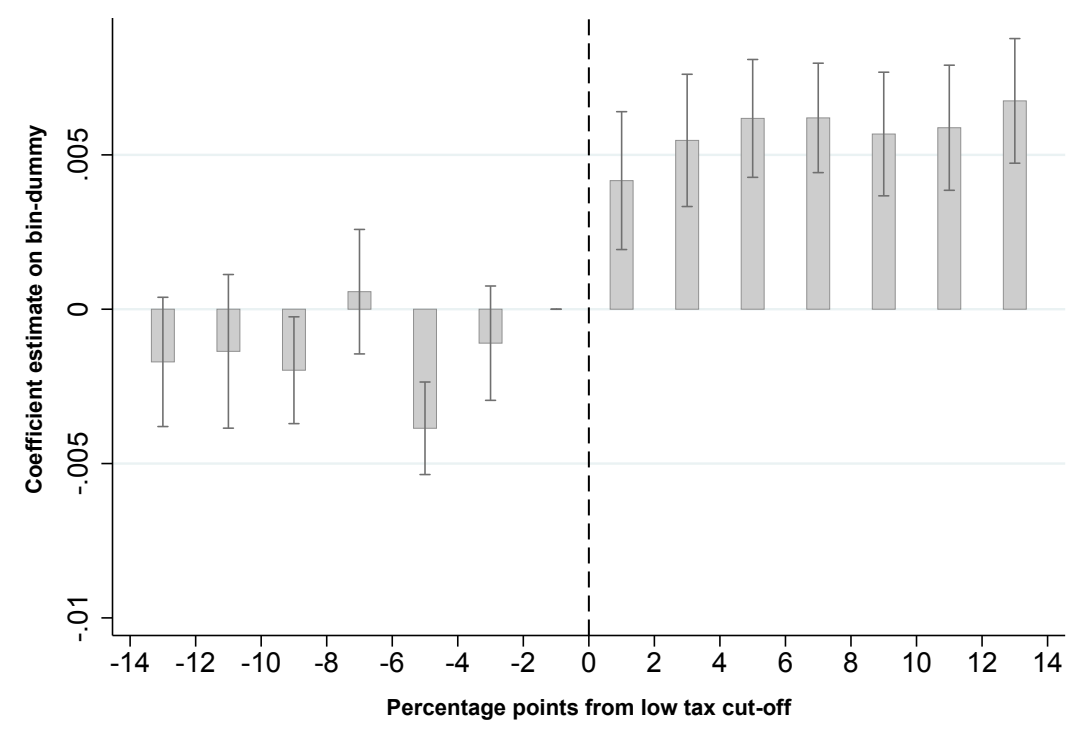

Notes: For each host-year pair, the probability for each home country with a CFC regime of setting up a new subsidiary in that specific host country that year is computed. The same calculation is made for all groups with parents in a non-CFC country.

For each home-host-year combination where home is a CFC country, we subtract the corresponding host-year probability from the unaffected groups. Only fully owned foreign subsidiaries are included. Incorporations from earlier years made by groups in home countries that later implement a CFC regime are dropped to avoid noise from anticipation effects (analogously for home countries that remove a CFC regime). Groups whose parent is based in a tax haven are not considered. In panel (a) bars represent the sum of probability-differences within $2 \mathrm{pp}$ bins relative to the cut-off. In panel (b) bars represent parameter estimates from a weighted regression of the probability differences on bin dummies describing the placement relative to the tax cut-off. We use the $[-2,0)$ bin as the base and include year fixed. Capped lines illustrate 95 percent confidence intervals calculated using the bootstrap approach with 1000 bootstrap replications. Using stratified resampling at the home-country level produces very similar standard errors. 
panel (b) shows coefficient estimates from this regression for the bins closest to the cut-off. ${ }^{23}$ From this figure we observe exactly the same pattern as earlier and further all coefficients for the bins just above the threshold are positive and statistically significant at the 5 percent level. These results again suggest that CFC affected groups have a significant excess probability compared to unaffected groups of incorporating above the threshold relative to below. ${ }^{24}$

Groups who are not subject to a CFC regime are subject to all the same remaining conditions determining location choice on foreign markets as groups under a CFC regime. Under this previously stated assumption CFC affected groups have a 0.4 percentage point higher probability of incorporating a new subsidiary in a host just above compared to just below the CFC low-tax threshold all else equal. This is a rather large effect given that the mean incorporation probability for a specific host in a given year is 1.5 percent. Furthermore this significant difference also exists for environments further up along the tax schedule suggesting that the total effect of CFC legislation on the location choice might be even larger in overall magnitude.

\section{Conclusions}

The prevalence of CFC legislation among both developed and developing economies today suggests a belief among policy makers in the effectiveness of this measure in curbing corporate tax avoidance. This belief is also expressed by the OECD in their 2015 final report on base erosion and profit shifting, BEPS (OECD/G20, 2015). The conclusions presented in this paper generally support this conviction. Studying the allocation of financial profit around tax thresholds embedded in current CFC legislation reveals large discontinuities consistent with a movement of profit into higher tax environments just above the threshold. Utilising reform time variation, we estimate a 14 percent reduction in financial profit upon entering CFC targeting. These results suggest that the potential tax penalty introduced by CFC legislation is

\footnotetext{
${ }^{23}$ Confidence bans are calculated using the bootstrap approach, to account for the uncertainty underlying the calculations of the probability-differences.

${ }^{24}$ Introducing the weights mentioned above in this regression framework results in very similar figures with the same qualitative characteristics.
} 
effective in redirecting profit away from very low-tax environments. These efforts by multinationals to avoid low-tax environments suggest that the measure is successful in eliminating the largest tax savings opportunities.

Studying the underlying behavioural patterns within the multinational firm reveals that the profit reduction within low-tax subsidiaries is accompanied by a subsequent increase within higher tax environments hereunder within subsidiaries on the domestic market. The consequence of such behaviour is an increase in corporate tax revenue both accruing to the rule enforcing country and other countries with similar tax levels. This means that CFC legislation can be used as an effective national policy tool towards protecting the domestic tax base and increasing national corporate tax revenues. In an international tax environment where coordination has proved challenging this is potentially an essential policy characteristic.

Accompanying these effects on the geographical allocation of profits is a response on the extensive margin of subsidiary location. By taxing across domestic borders targeting specific locations, CFC rules affect the discreet investment choice by affecting after tax returns. Using a control group of unaffected multinational groups, we show evidence that the location choice responds significantly to CFC rules, and that the magnitude of such responses might be large at least in the vicinity of embedded threshold values. This result suggests that CFC rules can be effective in discouraging multinationals from opening tax haven subsidiaries and subsidiaries in other low-tax environments for tax savings purposes. 


\section{REFERENCES}

[1] Altshuler, R., Hubbard, R.G., 2002. The effect of the tax reform act of 1986 on the location of assets in financial services firms. Journal of Public Economics 87, 109-127.

[2] Barrios, S., Huizinga, H., Laeven, L., Nicodeme, G., 2012. International taxation and multinational firm location decisions. Journal of Public Economics 96, 946-958.

[3] Buettner, T., Ruf, M., 2007. Tax incentives and the location of FDI: Evidence from a panel of German multinationals. International Tax and Public Finance 14, 151-164.

[4] Devereux, M.P., Griffith, R., 1998. Taxes and the location of production: evidence from a panel of US multinationals. Journal of Public Economics 68, 335-367.

[5] Devereux, M.P., Maffini, G., 2007. The impact of taxation on the location of capital, firms and profit: a survey of empirical evidence. Oxford University Centre for Business Taxation Working Paper 07/02, Oxford.

[6] Dharmapala, D., Riedel, N., 2013. Earnings shocks and tax-motivated income-shifting: Evidence from European multinationals. Journal of Public Economics 97, 95-107.

[7] Egger, P.H, Wamser, G., 2015. The impact of controlled foreign company legislation on real investments abroad. A multi-dimensional regression discontinuity design. Journal of Public Economics 129, 77-91.

[8] Halvorsen, R., Palmquist, R., 1980. The interpretation of dummy variables in semilogarithmic equations. The American Economic Review 70, Issue 3, June 474-475.

[9] Haufler, A., Mardan, M., Schindler, D., 2017. Double tax discrimination to attract FDI and fight profit shifting: The role of CFC rules. Oxford University Centre for Business Taxation Working Paper 17/02, Oxford.

[10] Heckemeyer, J.H., Overesch, M., 2013. Multinationals' profit response to tax differentials: Effect size and shifting channels. Centre for European Economic Research ZEW, Duscussion Paper No. 13-045. 
[11] Hines, J.R., 2010. Treasure Islands. Journal of Economic Perspectives, Volume 24, Number $4,103-126$.

[12] Huizinga, H., Laeven, L., 2008. International profit shifting within multinationals: A multi-country perspective. Journal of Public Economics 92, 1164-1182.

[13] International Fiscal Association (IFA), 2013 Copenhagen Congress. The taxation of foreign passive income for groups of companies. Cahiers de droit fiscal international volume 98a. Sdu Uitgevers, The Hague, The Netherlands.

[14] Mutti, J.H., Grubert, H., 2007. The effect of taxes on royalties and the migration of intangible assets abroad. NBER Working Paper No. 13248

[15] OECD/G20, 2015. Base Erosion and Profit Shifting Project - Explanatory Statement, Final Reports. http://www.oecd.org/ctp/beps-explanatory-statement-2015.pdf.

[16] OECD/G20, 2015. Base Erosion and Profit Shifting Project - Action 3: Designing effective controlled foreign company rules., Final Reports. http://www.oecd.org/tax/designingeffective-controlled-foreign-company-rules-action-3-2015-final-report-9789264241152en.htm.

[17] Ruf, M., Weichenrieder, A.J., 2012. The taxation of passive foreign investment: lessons from German experience. Canadian Journal of Economics, Vol. 45, No. 4, 1504-1528.

[18] Voget, J., 2011. Relocation of headquarters and international taxation. Journal of Public Economics 95, 1067-1081.

[19] Weichenrieder, A.J., 1996. Anti-tax-avoidance provisions and the size of foreign direct investment. International Tax and Public Finance 3, 67-81.

[20] Zucman, G., 2014. Taxing across borders: Tracking personal wealth and corporate profits. Journal of Economic Perspectives - Volume 28, Number 4, 121-148. 


\section{APPENDIX}

Figure 6:

Number of observations on key outcome variable in CFC affected groups by parent-country

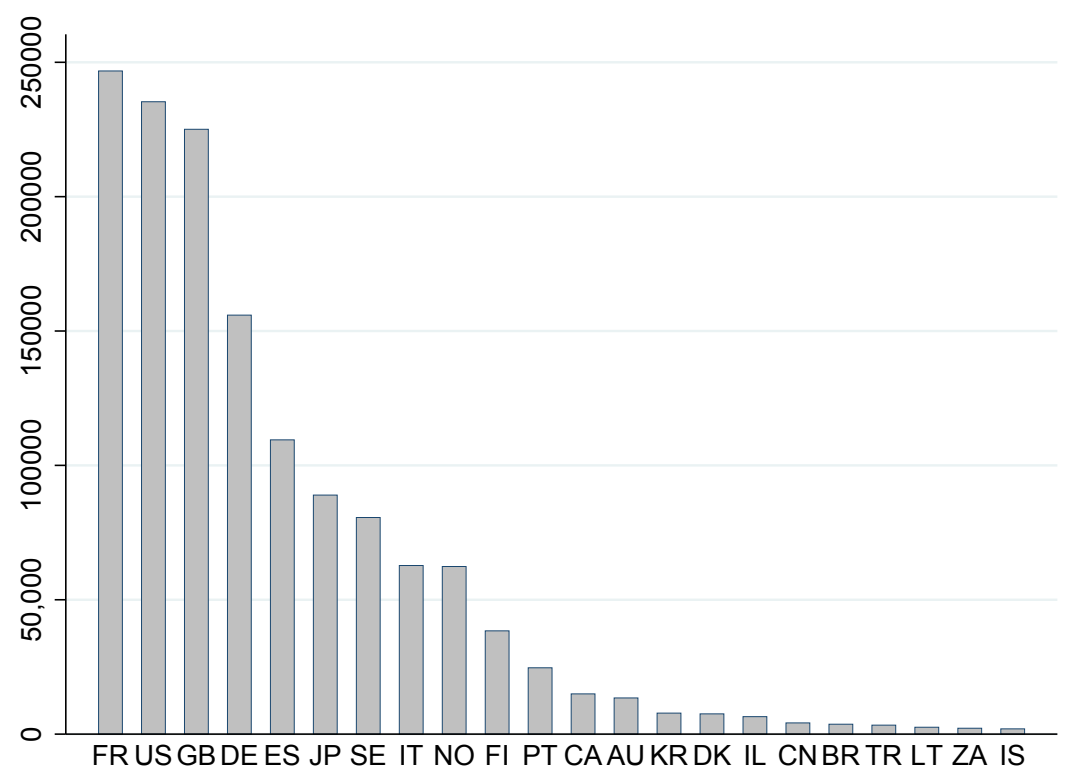

Notes: The figure shows the number of observations on the key outcome variable, financial profit, within multinational groups by home-country of the group parent. We only consider observations where the parent is located in a home country with an active CFC regime. All majority owned subsidiaries are included. 
Figure 7:

\section{Ratio of financial to operating profit around low-tax threshold (negatives incl.)}

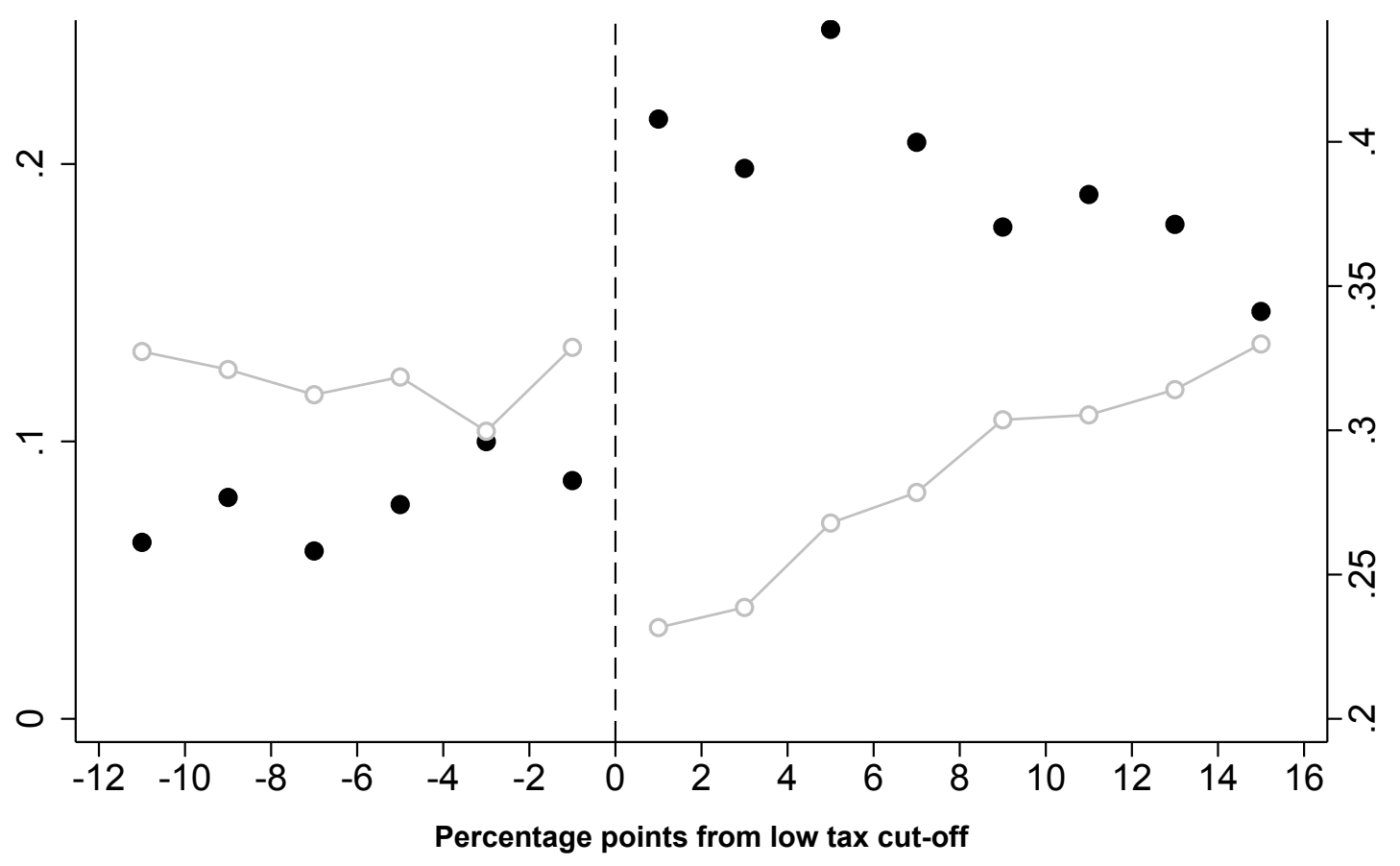

- Ratio of financial to operating profit (within bins) _—— Avg. tax rate on passive income

Notes: Filled circles represent the ratio of total financial profit to total operating profit within each 2 percentage point bin.

Hollow circles represent the average tax rate on passive income faced by the subsidiaries within each bin. Above zero (i.e. above the tax cut-off) this is the average host CTR faced by the subsidiaries in their respective host countries. Below zero (i.e. below the tax cut-off) this is the average home CTR i.e. the corporate tax rate in the country where the parent of the subsidiary is located. We condition on non-negative operating profit, but allow negative financial profit. Observations representing a single-year shift in the CFC indicator are excluded. We use only home-countries with an implemented CFC regime (with a specified tax threshold). All majority owned, foreign subsidiaries are included. We leave out domestic subsidiaries to avoid random fluctuations due to home-bias. We further exclude financial corporations and banks to assure that operating profit is a meaningful scaling variable. We are not able to extend the figure further to the left due to data coverage. The data availability at such low tax rates is very limited. 
Figure 8:

\section{Ratio of financial to operating profit around low tax cutoff (only fully owned subsidiaries)}

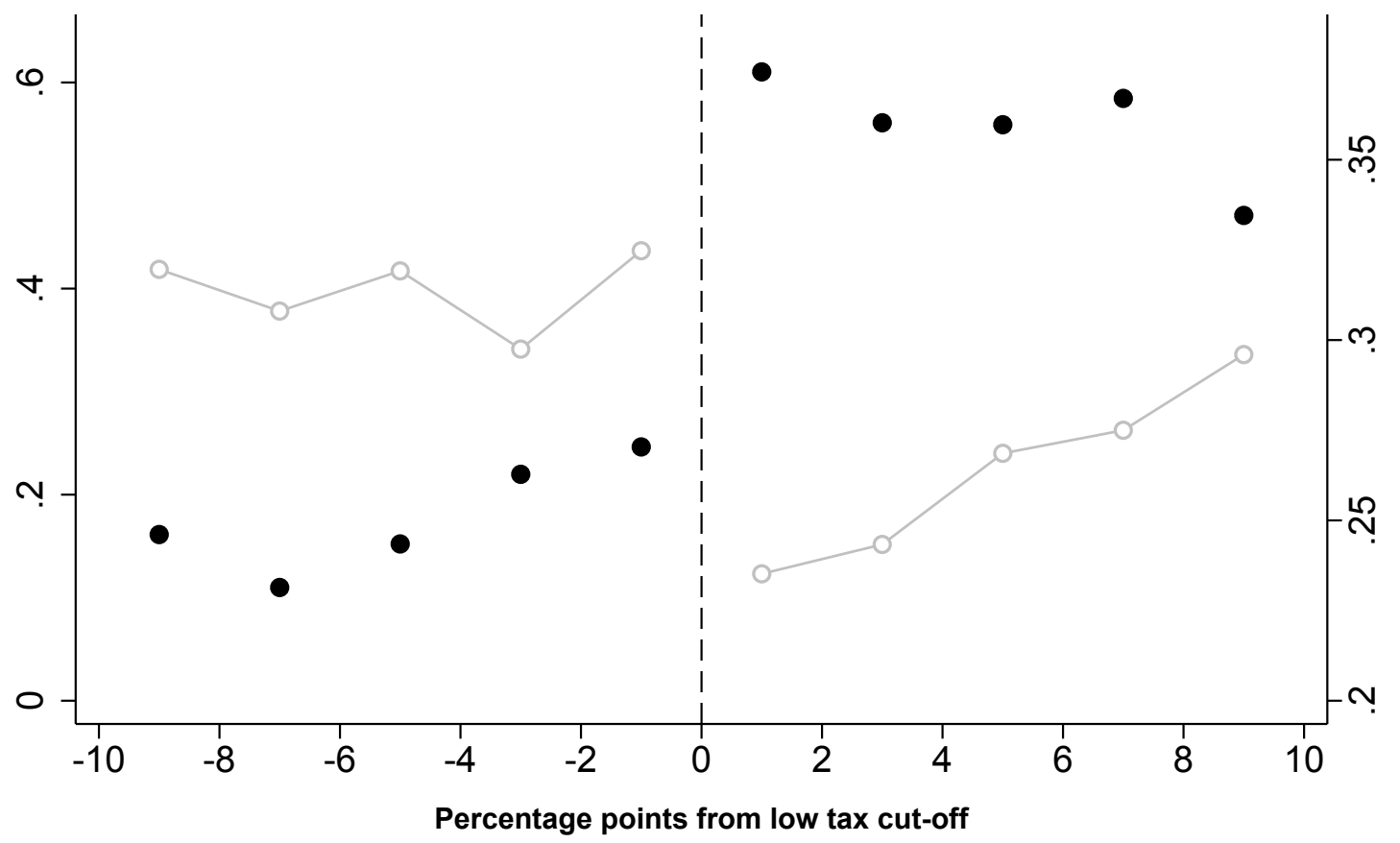

- Ratio of financial to operating profit (within bins) _ _ Avg. tax rate on passive income

Notes: Filled circles represent the ratio of total financial profit to total operating profit within each 2 percentage point bin.

Hollow circles represent the average tax rate on passive income faced by the subsidiaries within each bin. Above zero (i.e. above the tax cut-off) this is the average host CTR faced by the subsidiaries in their respective host countries. Below zero (i.e. below the tax cut-off) this is the average home CTR i.e. the corporate tax rate in the country where the parent of the subsidiary is located. We condition on non-negative operating- and financial profit, and observations representing a single-year shift in the CFC indicator are excluded. We use only home-countries with an implemented CFC regime (with a specified tax threshold), and only fully owned, foreign subsidiaries are included. We leave out domestic subsidiaries to avoid random fluctuations due to home-bias. We further exclude financial corporations and banks to assure that operating profit is a meaningful scaling variable. We limit the scope to a 20 pp range around the cut-off since conditioning on full ownership limits the sample considerably and hence data availability is very limited at considerably low and high tax rates. 
Figure 9:

\section{Linear probability model for financial profit ratio being above specified thresholds - Coefficient estimates of CFC targeting indicator}

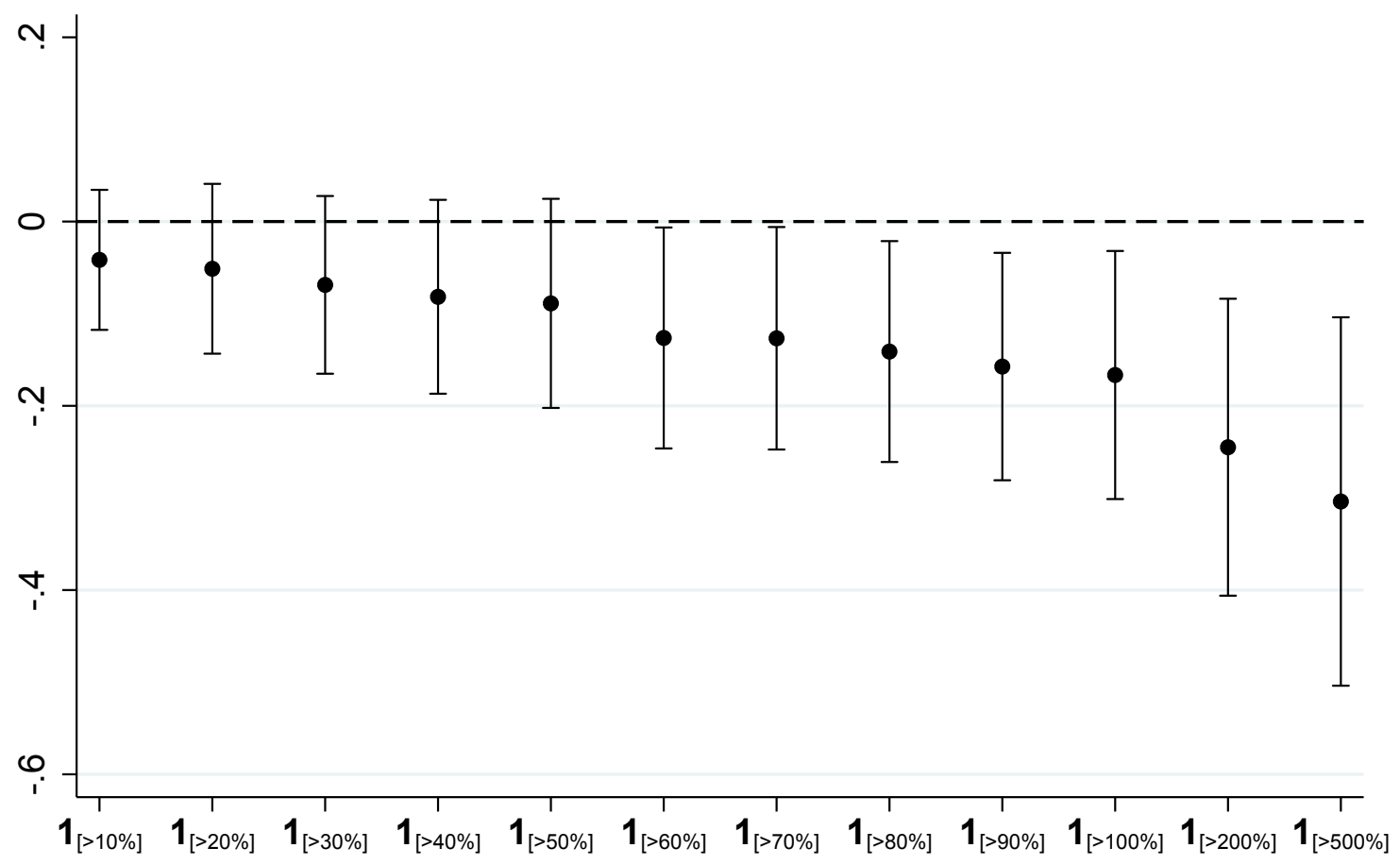

Notes: The LHS in each estimation is an indicator variable equal to one if the ratio of financial to operating profit is above the specified threshold indicated on the x-axis. Circles represent estimates of the coefficient on the CFC targeting indicator scaled by an estimate of the fraction of positives of the LHS variable, i.e. the CFC indicator estimate as a fraction of the baseline probability. Vertical capped lines represent $95 \%$ confidence intervals. Included host controls are: CTR, $\log ($ GDP), $\log ($ GDP PC), $\log$ (Corruption), $\log$ (Distance) and an indicator for being a domestic subsidiary. We use $\log ($ other assets) as subsidiary size control. All estimations include year FE and Parent FE. We condition on positive operating profit. Observations representing a single shift in the CFC indicator are excluded - this restriction never represents more than 200 excluded observations. We calculate standard errors using a bootstrap approach with clustered resampling at the group (parent) level and 1000 replications for each calculation. We use only home-countries with an implemented CFC regime, and only fully owned subsidiaries are included. Each estimation is based on a total of 290.538 observations. 
Figure 10:

\section{Linear probability model for financial profit ratio being above specified thresholds - Coefficient estimates of CFC targeting indicator}

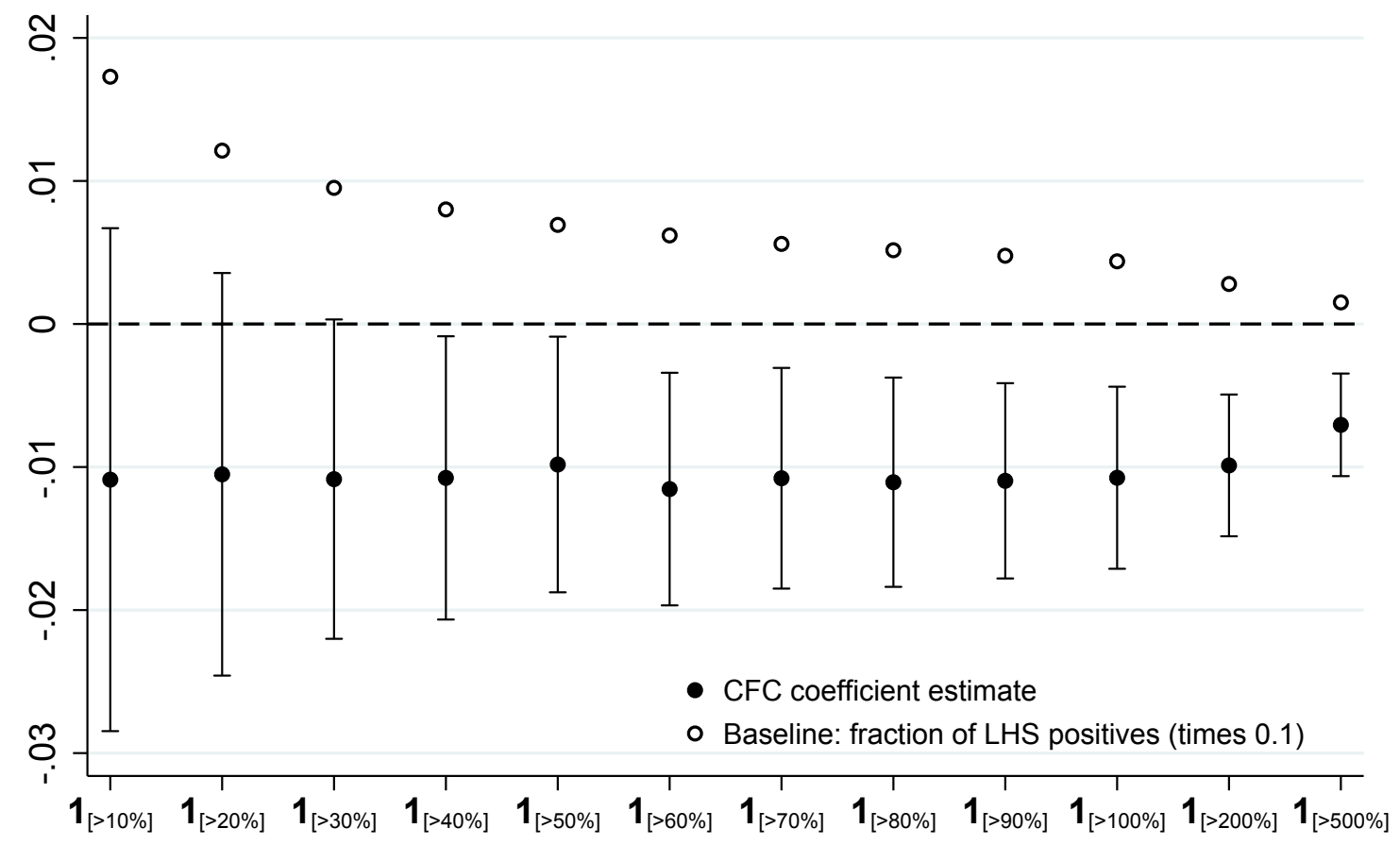

Notes: The LHS in each estimation is an indicator variable equal to one if the ratio of financial to operating profit is above the specified threshold indicated on the x-axis. Filled circles represent estimates of the coefficient on the CFC targeting indicator, and hollow circles represent the sample fraction of positives of the LHS variable (divided by 10 for the ease of exposition).

Vertical capped lines represent $95 \%$ confidence intervals. Included host controls are: CTR, log(GDP), $\log (\mathrm{GDP}$ PC),

$\log$ (Corruption), $\log$ (Distance) and an indicator for being a domestic subsidiary. We do not include a control on the RHS for subsidiary size since the LHS variable is scaled by total operating profit. All estimations include year FE and Parent FE. We condition on positive operating profit. Observations representing a single shift in the CFC indicator are excluded - this restriction never represents more than 200 excluded observations. We use only home-countries with an implemented CFC regime, and only fully owned subsidiaries are included. Each estimation is based on a total of 310.988 observations. 
Figure 11:

\section{Number of new incorporations in CFC affected groups (2003-2013) by parent-country}

(a) All majority owned subsidiaries

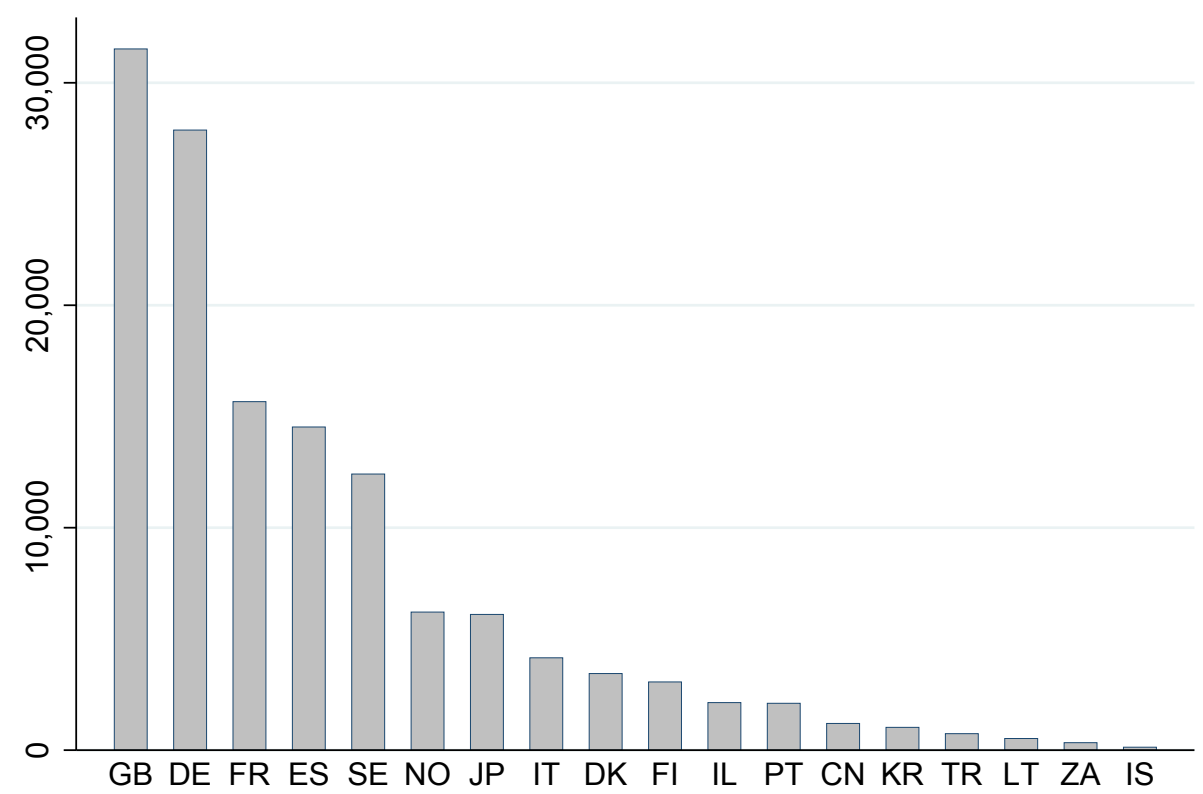

(b) Fully owned foreign subsidiaries

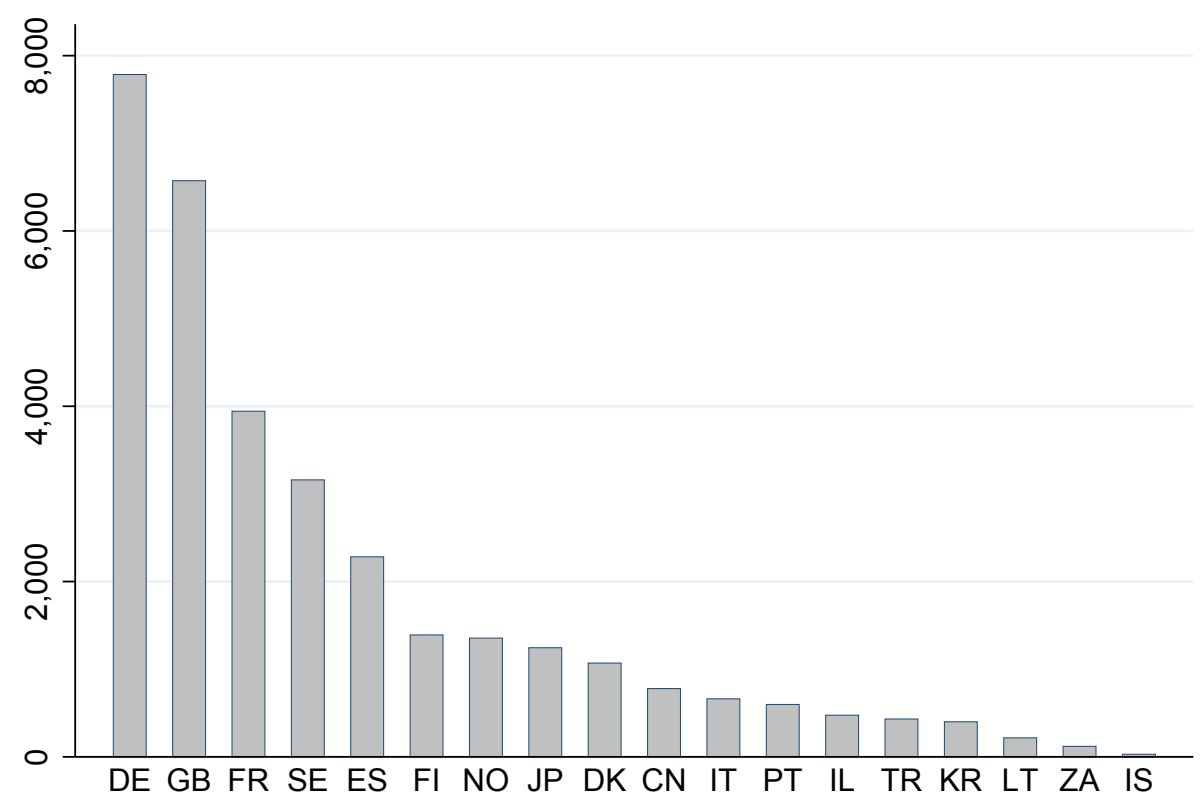

Notes: Each panel shows the number of new incorporations within multinational groups by home-country of the group parent. We only consider incorporations where the parent is located in a home country with an active CFC regime including a low-tax cut-off. Panel (a) includes all majority owned new incorporations including domestic subsidiaries, while panel (b) only includes new foreign subsidiaries that are fully owned. 
Figure 12:

\section{Number of new incorporations in groups not affected by a CFC low tax threshold (2003-2013) by parent-country}

(a) Fully owned foreign subsidiaries - all countries (> $500 \mathrm{obs)}$

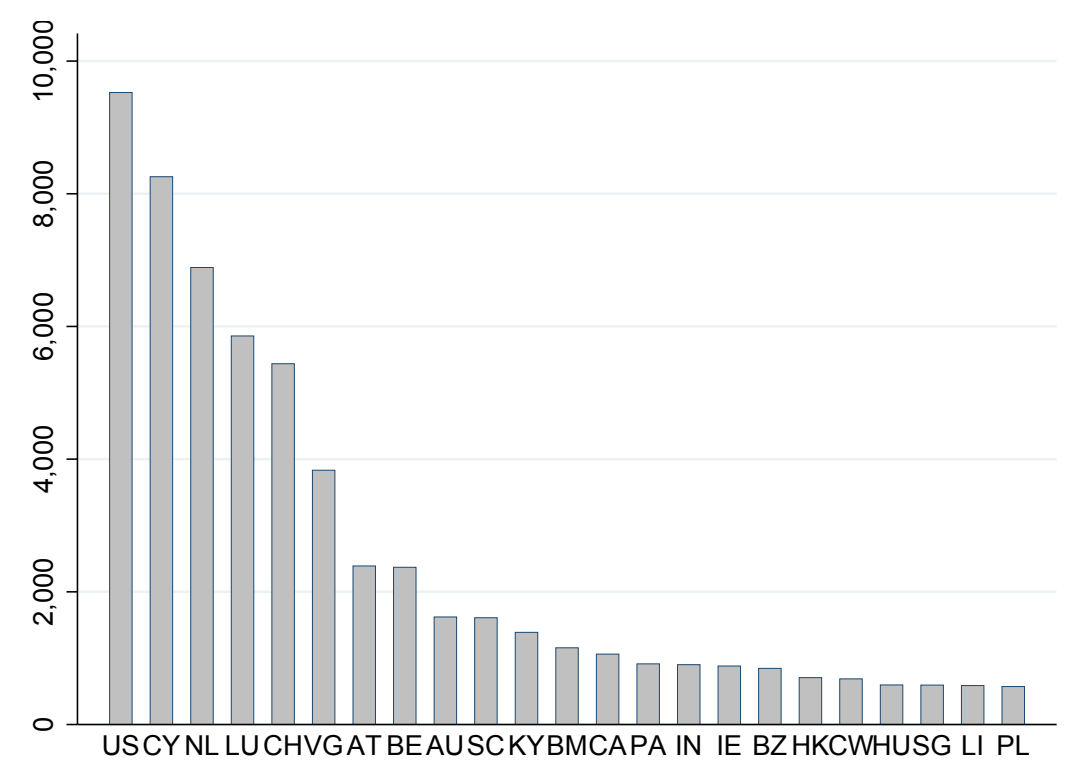

(b) Fully owned foreign subsidiaries - excl. tax havens and US, $\mathrm{CA}, \mathrm{BR}, \mathrm{AU}(>100 \mathrm{obs})$

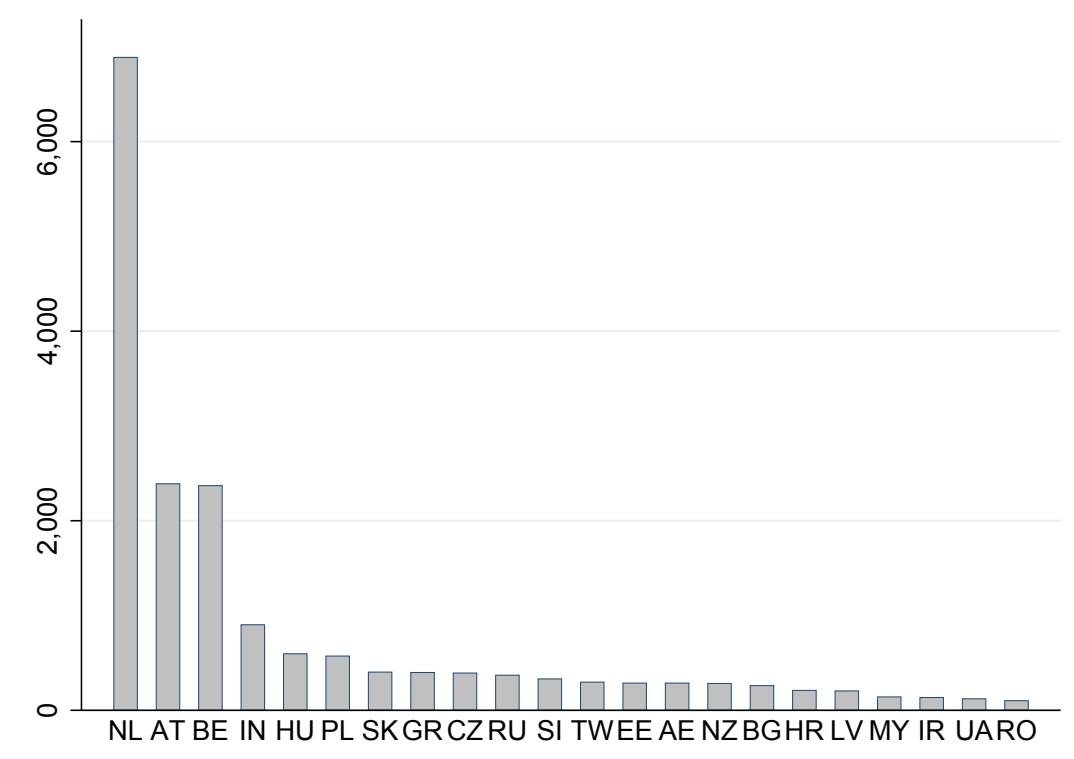

Notes: Each panel shows the number of new incorporations within multinational groups by home-country of the group parent. We only consider incorporations where the parent is located in a home country without a CFC regime or with a CFC regime not including a low-tax cut-off. Panel (a) includes all fully owned foreign new incorporations in all Non-CFC countries and US, $\mathrm{CA}, \mathrm{Br}$ and $\mathrm{AU}$ (CFC countries without cut-off), while panel (b) only includes non-CFC countries that do not classify as a tax haven country. 
Figure 13:

\section{Sum of differences in incorporation probabilities (groups affected by CFC cut-off vs. non-affected groups)}

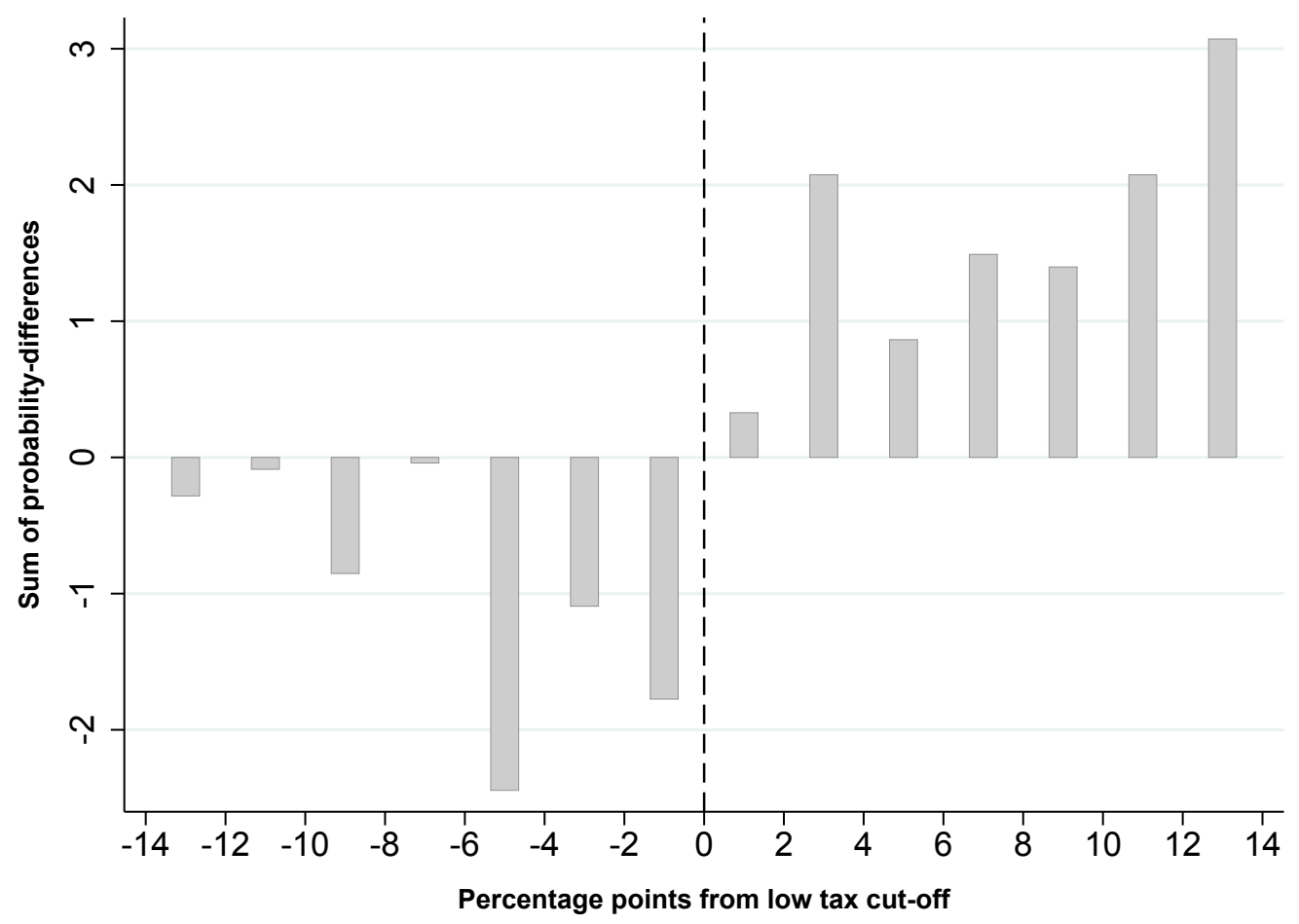

Notes: For each host-year pair, the probability for each CFC home country with a low-tax cut-off of setting up a new subsidiary in that specific host country that year is computed (calculated as the number of incorporations in that host-year combination divided by the total number of incorporations that year). The same calculation is made for all groups with parents in a Non-CFC country. For each home-host-year combination where the home country is a CFC country with a low tax threshold, we subtract the corresponding host-year probability from the non-CFC affected groups. This produces a collection of differences in incorporation probabilities that are sorted relative to the relevant tax threshold and summed within bins. Bars represent the sum of these over-probabilities within 2pp bins relative to the cut-off. Only fully owned foreign subsidiaries are included in these calculations. Furthermore incorporations from earlier years made by groups in home countries that later implement a CFC regime are dropped to avoid noise from anticipation effects (analogously incorporations in later years from home countries that remove a CFC regime are also dropped). In the collection of non-affected groups we include all groups where the parent is located in a home country that does not have CFC legislation, or in one of the four countries with CFC rules not containing a low tax threshold (US, CA, BR and AU). 
Figure 14:

\section{Differences in incorporation probabilities (groups affected by CFC legislation versus unaffected groups)}

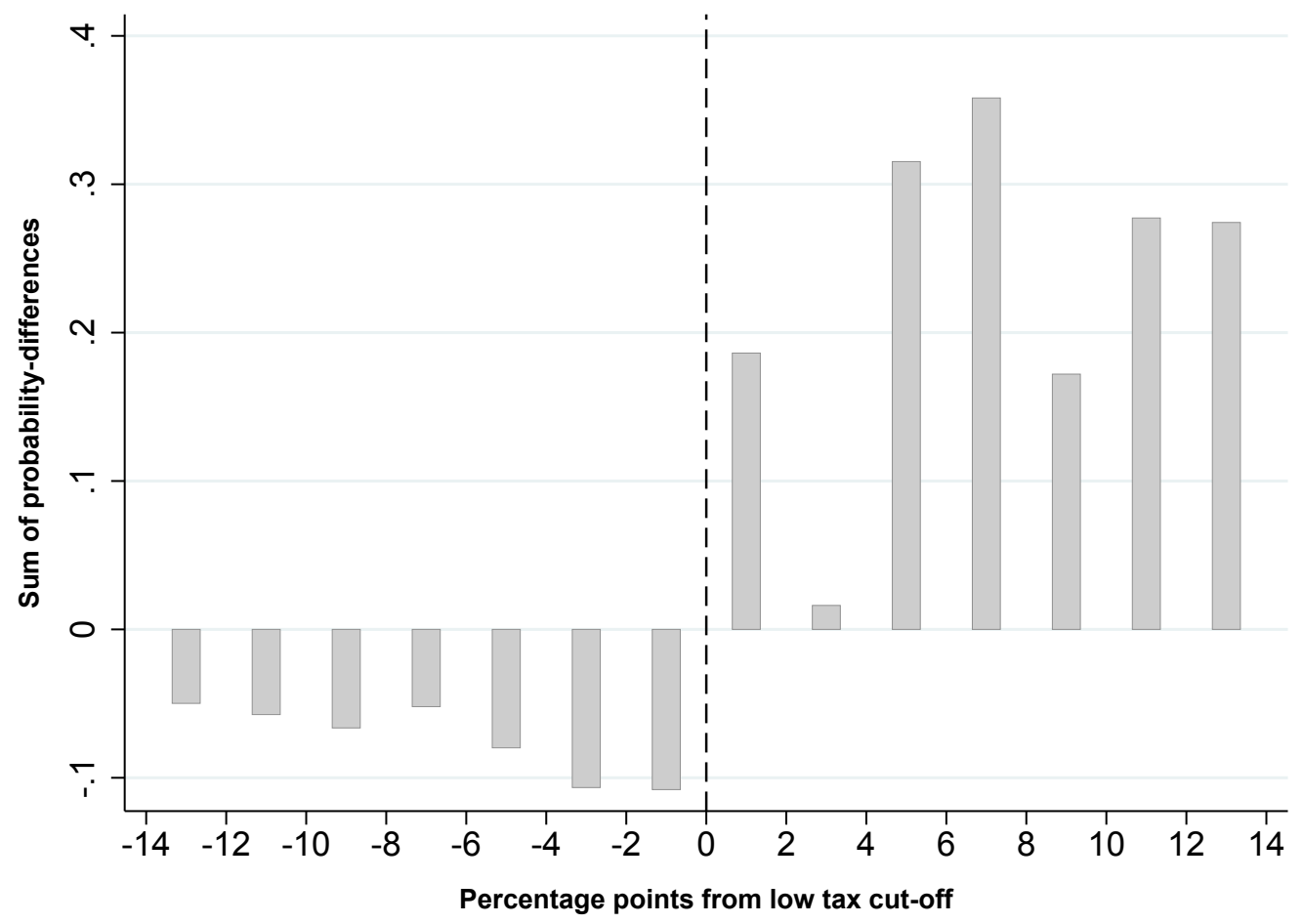

Notes: For each host-year pair, the probability for each CFC home country with a low-tax cut-off of setting up a new subsidiary in that specific host country that year is computed (calculated as the number of incorporations in that host-year combination divided by the total number of incorporations that year). The same calculation is made for all groups with parents in a Non-CFC country. For each home-host-year combination where the home country is a CFC country with a low tax threshold, we subtract the corresponding host-year probability from the unaffected groups. This produces a collection of differences in incorporation probabilities that are sorted relative to the relevant tax threshold and summed within bins. Bars represent the sum of these over-probabilities within 2pp bins relative to the cut-off. Only fully owned foreign subsidiaries are included in these calculations. Furthermore incorporations from earlier years made by groups in home countries that later implement a CFC regime are dropped to avoid noise from anticipation effects (analogously incorporations in later years from home countries that remove a CFC regime are also dropped). We limit the collection of non-affected groups to include only groups where the parent is located in a home country that does not classify as a tax haven country and that does not have CFC legislation. Each observation representing a home-host-year combination is weighted by a weight calculated as the share of total new incorporations in the year in question which are attributable to the specific home country. I.e. weights sum to one across the 18 home-countries within years. 
Table 4:

\section{Descriptive statistics}

\begin{tabular}{|c|c|c|c|c|c|c|}
\hline & Obs & Mean & Std.Dev. & Median & Min & Max \\
\hline \multicolumn{7}{|l|}{ Full sample of subsidiaries ${ }^{1}$} \\
\hline Host corporate tax rate & 11100037 & 29.62 & 7.80 & 30 & 0 & 55 \\
\hline Total Assets & 3186660 & 291235 & $1.08 \cdot 10^{7}$ & 3481 & $-1.68 \cdot 10^{7}$ & $9.13 \cdot 10^{9}$ \\
\hline Intangible Fixed Assets & 2564526 & 3973 & $1.69 \cdot 10^{6}$ & 0 & $-1.48 \cdot 10^{6}$ & $2.70 \cdot 10^{9}$ \\
\hline Operating Profit & 2234784 & 5017 & $3.92 \cdot 10^{6}$ & 58 & $-4.05 \cdot 10^{8}$ & $5.83 \cdot 10^{9}$ \\
\hline Financial Profit & 2275430 & 2792 & $0.80 \cdot 10^{6}$ & 0 & $-1.76 \cdot 10^{8}$ & $1.17 \cdot 10^{9}$ \\
\hline Nr Employees & 2034179 & 232 & 2315 & 25 & 0 & $5.99 \cdot 10^{5}$ \\
\hline Size of group ${ }^{2}$ & 11302709 & 229 & 432 & 49 & 1 & 2606 \\
\hline Home corporate tax rate & 10969801 & 30.37 & 8.83 & 30 & 0 & 55 \\
\hline \multicolumn{7}{|l|}{ Sample of CFC affected subsidiaries ${ }^{3}$} \\
\hline Host corporate tax rate & 4417881 & 29.88 & 6.72 & 30 & 0 & 55 \\
\hline Total Assets & 1530846 & 369675 & $1.17 \cdot 10^{7}$ & 4052 & $-0.63 \cdot 10^{6}$ & $3.13 \cdot 10^{9}$ \\
\hline Intangible Fixed Assets & 1217045 & 3472 & $0.11 \cdot 10^{6}$ & 0 & $-1.03 \cdot 10^{6}$ & $2.84 \cdot 10^{7}$ \\
\hline Operating Profit & 1104215 & 2205 & $0.50 \cdot 10^{6}$ & 89 & $-4.05 \cdot 10^{8}$ & $1.86 \cdot 10^{8}$ \\
\hline Financial Profit & 1131036 & 4507 & $1.13 \cdot 10^{6}$ & 0 & $-1.76 \cdot 10^{8}$ & $1.17 \cdot 10^{9}$ \\
\hline Nr Employees & 897245 & 247 & 2735 & 28 & 0 & $5.99 \cdot 10^{5}$ \\
\hline Size of group & 4471288 & 289 & 495 & 69 & 1 & 2606 \\
\hline Home corporate tax rate CTR & 4471288 & 31.22 & 4.90 & 30 & 15 & 42 \\
\hline CFC targeted subs in group & 4468190 & 22 & 57 & 1 & 0 & 634 \\
\hline CFC cut-off (specified in home country) & 4471288 & 20.56 & 3.94 & 21 & 10 & 26.25 \\
\hline
\end{tabular}


Table 5:

\section{CFC rules and the allocation of financial profit within multinationals}

\begin{tabular}{|c|c|c|c|c|c|c|}
\hline & \multicolumn{6}{|c|}{ Outcome: $\ln$ (financial profit) } \\
\hline & (1) & $(2)$ & $(3)$ & $(4)$ & $(5)$ & (6) \\
\hline CFC Indicator & $\begin{array}{c}-1.056^{* * *} \\
(0.212)\end{array}$ & $\begin{array}{c}-0.750^{* * *} \\
(0.132)\end{array}$ & $\begin{array}{c}-0.446^{* * *} \\
(0.132)\end{array}$ & $\begin{array}{c}-0.289^{* * *} \\
(0.102)\end{array}$ & $\begin{array}{c}-0.460^{* * *} \\
(0.122)\end{array}$ & $\begin{array}{l}-0.283^{* * *} \\
(0.090)\end{array}$ \\
\hline CTR & $\begin{array}{r}-0.001 \\
(0.013)\end{array}$ & $\begin{array}{l}-0.063^{* * *} \\
(0.012)\end{array}$ & $\begin{array}{c}-0.046^{* * *} \\
(0.014)\end{array}$ & $\begin{array}{l}-0.053^{* * *} \\
(0.008)\end{array}$ & & \\
\hline $\mathrm{CTR} \times \mathrm{CFC}$ & & & & & $\begin{array}{c}0.032 \\
(0.022)\end{array}$ & $\begin{array}{c}0.024 \\
(0.018)\end{array}$ \\
\hline $\mathrm{CTR} \times(1-\mathrm{CFC})$ & & & & & $\begin{array}{l}-0.052^{* * *} \\
(0.015)\end{array}$ & $\begin{array}{l}-0.059^{* * *} \\
(0.008)\end{array}$ \\
\hline $\ln (\mathrm{GDP})$ & & $\begin{array}{l}0.371^{* * *} \\
(0.048)\end{array}$ & $\begin{array}{l}0.260^{* * *} \\
(0.048)\end{array}$ & $\begin{array}{l}0.173^{* * *} \\
(0.032)\end{array}$ & $\begin{array}{l}0.259^{* * *} \\
(0.050)\end{array}$ & $\begin{array}{l}0.172^{* * *} \\
(0.033)\end{array}$ \\
\hline $\ln (\mathrm{GDPPC})$ & & $\begin{array}{r}0.095 \\
(0.154)\end{array}$ & $\begin{array}{l}0.888^{* * *} \\
(0.180)\end{array}$ & $\begin{array}{r}-0.028 \\
(0.109)\end{array}$ & $\begin{array}{l}0.859^{* * *} \\
(0.173)\end{array}$ & $\begin{array}{r}-0.026 \\
(0.105)\end{array}$ \\
\hline $\ln$ (Corrup) & & $\begin{array}{l}1.394^{* * *} \\
(0.227)\end{array}$ & $\begin{array}{l}0.939^{* * *} \\
(0.164)\end{array}$ & $\begin{array}{l}0.842^{* * *} \\
(0.131)\end{array}$ & $\begin{array}{l}1.005^{* * *} \\
(0.166)\end{array}$ & $\begin{array}{l}0.894^{* * *} \\
(0.136)\end{array}$ \\
\hline $\ln ($ Distance $)$ & & $\begin{array}{l}-0.140^{* * *} \\
(0.040)\end{array}$ & $\begin{array}{c}-0.068^{* *} \\
(0.034)\end{array}$ & $\begin{array}{l}0.027 \\
(0.024)\end{array}$ & $\begin{array}{l}-0.072^{* *} \\
(0.033)\end{array}$ & $\begin{array}{c}0.025 \\
(0.024)\end{array}$ \\
\hline Dom. Ind & & $\begin{array}{l}0.407^{* * *} \\
(0.079)\end{array}$ & $\begin{array}{l}0.235^{* * *} \\
(0.089)\end{array}$ & $\begin{array}{l}0.244^{* * *} \\
(0.034)\end{array}$ & $\begin{array}{l}0.238^{* * *} \\
(0.089)\end{array}$ & $\begin{array}{l}0.246^{* * *} \\
(0.035)\end{array}$ \\
\hline $\ln (\mathrm{Nr} \mathrm{Emp})$ & & & $\begin{array}{l}0.430 \text { *** } \\
(0.025)\end{array}$ & & $\begin{array}{l}0.429 \text { *** } \\
(0.025)\end{array}$ & \\
\hline $\ln$ (Other Assets) & & & & $\begin{array}{l}0.947^{* * *} \\
(0.014)\end{array}$ & & $\begin{array}{l}0.947^{* * *} \\
(0.014)\end{array}$ \\
\hline Parent $\times$ year $\mathrm{FE}$ & & $\checkmark$ & $\checkmark$ & $\checkmark$ & $\checkmark$ & $\checkmark$ \\
\hline Obs (total) & 197034 & 196954 & 114103 & 177843 & 114103 & 177843 \\
\hline Obs (w. $\mathrm{CFC}=1)$ & 12140 & 12138 & 8691 & 11247 & 8691 & 11247 \\
\hline$R^{2}(\operatorname{adj})$ & 0.01 & 0.18 & 0.24 & 0.62 & 0.24 & 0.62 \\
\hline
\end{tabular}

Notes: The unit of observation is subsidiaries of parents located in CFC countries with a specified low-tax threshold while the dependent variable is the natural logarithm of financial profit. Observations representing a single-year shift in the CFC indicator, are excluded in all specifications - this restriction never represents more than 200 excluded observations. All specifications include only fully owned subsidiaries. In Column (5) and (6) the host corporate tax rate (CTR) is centered around a value of 18 percent. Standard errors in parentheses, clustered at the country-year level. ${ }^{* * *} \mathrm{p}<0.01,{ }^{* *} \mathrm{p}<0.05,{ }^{*} \mathrm{p}<0.1$ 
Table 6:

\section{CFC rules and the allocation of financial profit within multinationals (majority ownership of subsidiaries)}

\begin{tabular}{|c|c|c|c|c|c|c|}
\hline & \multicolumn{6}{|c|}{ Outcome: $\ln$ (financial profit) } \\
\hline & (1) & $(2)$ & $(3)$ & $(4)$ & $(5)$ & (6) \\
\hline CFC Indicator & $\begin{array}{l}-1.152^{* * *} \\
(0.200)\end{array}$ & $\begin{array}{l}-0.711^{* * *} \\
(0.106)\end{array}$ & $\begin{array}{l}-0.487^{* * *} \\
(0.094)\end{array}$ & $\begin{array}{l}-0.326^{* * *} \\
(0.086)\end{array}$ & $\begin{array}{l}-0.509^{* * *} \\
(0.093)\end{array}$ & $\begin{array}{l}-0.341^{* * *} \\
(0.078)\end{array}$ \\
\hline CTR & $\begin{array}{c}-0.020^{* *} \\
(0.010)\end{array}$ & $\begin{array}{l}-0.064^{* * *} \\
(0.009)\end{array}$ & $\begin{array}{c}-0.054^{* * *} \\
(0.010)\end{array}$ & $\begin{array}{l}-0.050^{* * *} \\
(0.007)\end{array}$ & & \\
\hline $\mathrm{CTR} \times \mathrm{CFC}$ & & & & & $\begin{array}{c}0.001 \\
(0.015)\end{array}$ & $\begin{array}{c}0.019 \\
(0.016)\end{array}$ \\
\hline $\mathrm{CTR} \times(1-\mathrm{CFC})$ & & & & & $\begin{array}{c}-0.057^{* * *} \\
(0.010)\end{array}$ & $\begin{array}{c}-0.054^{* * *} \\
(0.008)\end{array}$ \\
\hline $\ln (\mathrm{GDP})$ & & $\begin{array}{l}0.282^{* * *} \\
(0.036)\end{array}$ & $\begin{array}{l}0.191^{* * *} \\
(0.035)\end{array}$ & $\begin{array}{l}0.129^{* * *} \\
(0.028)\end{array}$ & $\begin{array}{l}0.188^{* * *} \\
(0.036)\end{array}$ & $\begin{array}{l}0.126^{\text {**** }} \\
(0.028)\end{array}$ \\
\hline $\ln (\mathrm{GDPPC})$ & & $\begin{array}{c}0.089 \\
(0.130)\end{array}$ & $\begin{array}{l}0.732^{* * *} \\
(0.124)\end{array}$ & $\begin{array}{c}-0.191^{* *} \\
(0.083)\end{array}$ & $\begin{array}{l}0.699^{* * *} \\
(0.122)\end{array}$ & $\begin{array}{c}-0.209^{* *} \\
(0.081)\end{array}$ \\
\hline $\ln$ (Corrup) & & $\begin{array}{l}1.296^{* * *} \\
(0.162)\end{array}$ & $\begin{array}{l}1.077^{* * *} \\
(0.105)\end{array}$ & $\begin{array}{l}0.926^{* * *} \\
(0.104)\end{array}$ & $\begin{array}{l}1.121^{* * *} \\
(0.110)\end{array}$ & $\begin{array}{l}0.971^{* * *} \\
(0.109)\end{array}$ \\
\hline $\ln ($ Distance $)$ & & $\begin{array}{c}-0.065^{* *} \\
(0.030)\end{array}$ & $\begin{array}{c}0.012 \\
(0.024)\end{array}$ & $\begin{array}{l}0.048^{* * *} \\
(0.018)\end{array}$ & $\begin{array}{r}0.009 \\
(0.024)\end{array}$ & $\begin{array}{c}0.044 \\
(0.018)\end{array}$ \\
\hline Dom. Ind & & $\begin{array}{l}0.347^{* * *} \\
(0.056)\end{array}$ & $\begin{array}{l}0.182^{\text {*** }} \\
(0.065)\end{array}$ & $\begin{array}{l}0.215^{* * *} \\
(0.029)\end{array}$ & $\begin{array}{l}0.186^{* * *} \\
(0.065)\end{array}$ & $\begin{array}{l}0.217^{* * *} \\
(0.029)\end{array}$ \\
\hline $\ln (\mathrm{Nr}$ Emp $)$ & & & $\begin{array}{l}0.488^{* * *} \\
(0.021)\end{array}$ & & $\begin{array}{l}0.487^{* * *} \\
(0.021)\end{array}$ & \\
\hline $\ln$ (Other Assets) & & & & $\begin{array}{l}0.943^{* * *} \\
(0.011)\end{array}$ & & $\begin{array}{l}0.942^{* * *} \\
(0.011)\end{array}$ \\
\hline Parent FE & & $\checkmark$ & $\checkmark$ & $\checkmark$ & $\checkmark$ & $\checkmark$ \\
\hline Year FE & & $\checkmark$ & $\checkmark$ & $\checkmark$ & $\checkmark$ & $\checkmark$ \\
\hline Obs (total) & 422386 & 422105 & 250842 & 384278 & 250842 & 384278 \\
\hline Obs (w. $\mathrm{CFC}=1)$ & 23582 & 23572 & 16610 & 21925 & 16610 & 21925 \\
\hline$R^{2}(\operatorname{adj})$ & 0.01 & 0.24 & 0.32 & 0.63 & 0.32 & 0.63 \\
\hline
\end{tabular}

Notes: The unit of observation is subsidiaries of parents located in CFC countries with a specified low-tax threshold while the dependent variable is the natural logarithm of financial profit. Observations representing a single-year shift in the CFC indicator, are excluded in all specifications - this restriction never represents more than 450 excluded observations. All specifications include all majority owned subsidiaries. In Column (5) and (6) the host corporate tax rate (CTR) is centered around a value of 18 percent. Standard errors in parentheses, clustered at the country-year level. *** $\mathrm{p}<0.01,{ }^{*} \mathrm{p}<0.05, * \mathrm{p}<0.1$ 
Table 7:

Overview of CFC legislation during the sample period 2003-2013

\begin{tabular}{|c|c|c|c|c|c|c|}
\hline Country & $\begin{array}{l}\text { Year of } \\
\text { intro. }\end{array}$ & $\begin{array}{l}\text { Concerning } \\
\text { years }\end{array}$ & $\begin{array}{c}\text { Tax } \\
\text { cut-off }\end{array}$ & Country list & Control requirement & $\begin{array}{l}\text { Exemption related to type of income/ } \\
\text { assets }\end{array}$ \\
\hline Australia & 1990 & $2003-2013^{25}$ & - & Grey list & $\begin{array}{l}\text { Three tests of control: (i) Strict control: }>50 \% \\
\text { interest owned by } 5 \text { or less res. shareh. (must be } \\
1 \% \text { entities and control is associate inclusive - AI). } \\
\text { (ii) Objective de facto: Single res. entity with (AI) } \\
\text { control interest of }>40 \% \text { (unless control elsewhere } \\
\text { can be proven). (iii) Subjective de facto: Other } \\
\text { forms of "control" in economic sense by } 5 \text { or fewer } \\
\text { res. entities. Further: Separate entity only attributable } \\
\text { taxpayer if it has (AI) control interest }>10 \% \text { (unless } \\
\text { special rule of }>1 \% \text { if control is based on (iii)) }\end{array}$ & $\begin{array}{l}\text { Active income test: several conditions on } \\
\text { transparency and compliance with } \\
\text { accounting principle plus tainted income } \\
\text { ratio must be less than } 5 \% \text {. If entity } \\
\text { passes this test, it is excluded. De } \\
\text { minimis: Entity is in a listed country } \\
\text { AND EDCI }{ }^{26}<\min (\text { AUD } 50.000,5 \% \text { of } \\
\text { gross turnover) }\end{array}$ \\
\hline Brazil & 2001 & $2003-2013$ & - & - & $\begin{array}{l}\text { Company must be either controlled or affiliated. } \\
\text { Controlled: shareh. has rights assuring influence over } \\
\text { business decisions and power to appoint majority of } \\
\text { administrators (directors or officers). Affiliated: } \\
\text { requires "relevant influence" - this is assumed when } \\
>20 \% \text { of voting stock is owned. }\end{array}$ & -27 \\
\hline Canada & 1972 & $2003-2013$ & - & - & $\begin{array}{l}\text { Taxpayer's equity percentage }>1 \% \text { and total equity } \\
\text { percentage of taxpayer and related persons }>10 \% \text {. } \\
\text { Further taxpayer (along with the three classes of } \\
\text { persons) }{ }^{28} \text { must have voting control. }\end{array}$ & If tainted (FAPI) income $<\$ 5.000$ \\
\hline
\end{tabular}

Continued on next page

\footnotetext{
25 In 2011 a draft for new CFC legislation was published. The draft suggest changes to the definition of control, as well as a significant reduction in the types of income that is potentially attributable under the $\mathrm{CFC}$ rules - the draft suggests more focus on actual passive income. It is so far unknown, when the changes will take effect.

26 EDCI: "Eligible designated concession income" - refers to income in (listed) countries that is not deemed "comparably taxed", i.e. income benefiting from preferential regime or a gap in tax base.

27 The Brazilian CFC regime is extraordinarily strict in the sense that it targets both passive and active income, and also includes subsidiaries that are not necessarily controlled. This has led to court-cases with allegations of violations of the constitution, and criticism for being a system more focused on generating revenue than fighting tax avoidance.

28 The three classes of persons: 1. persons not dealing at arm's length with the taxpayer. 2.Any four Canadian resident persons - there does not have to be any relationship between the taxpayer and the four other Canadian shareholders. 3. Persons not dealing at arm's length with the four shareholders mentioned earlier.
} 
Table 7 - Continued from previous page

\begin{tabular}{|c|c|c|c|c|c|c|}
\hline Country & $\begin{array}{l}\text { Year of } \\
\text { intro. }\end{array}$ & $\begin{array}{c}\text { Concerning } \\
\text { years }\end{array}$ & $\begin{array}{c}\text { Tax } \\
\text { cut-off }\end{array}$ & Country list & Control requirement & $\begin{array}{l}\text { Exemption related to type of income/ } \\
\text { assets }\end{array}$ \\
\hline China & 2008 & $2008-2013$ & $50 \%$ & White list ${ }^{29}$ & $\begin{array}{l}>10 \% \text { of shares with voting rights and }>50 \% \text { of } \\
\text { shares w. other res. shareholders. Or effective control. }\end{array}$ & $\begin{array}{l}\text { If "mainly" active (in practice: }>50 \% \\
\text { active income) }\end{array}$ \\
\hline Denmark & 1995 & $2003-2006$ & $75 \%$ & - & Controlling interest & $\begin{array}{l}<33.3 \% \text { of total taxable income is } \\
\text { financial }\end{array}$ \\
\hline Denmark & 1995 & $2007-2013$ & - & - & $\begin{array}{l}\text { "Decision-making influence": > } 50 \% \text { of } \\
\text { voting rights }\end{array}$ & $\begin{array}{l}<50 \% \text { of taxable income is tainted }<10 \\
\% \text { of total assets are financial }\end{array}$ \\
\hline Finland & 1995 & $2003-2013$ & $60 \%$ & Blacklist & $\begin{array}{l}>50 \% \text { capital or voting rights, or entitled to }>50 \% \\
\text { of yield of net wealth - aggr. across res. shareh. AND } \\
\text { each shareh. }>25 \% \text { interest. }\end{array}$ & $\begin{array}{l}\text { If income mainly from shipping, indus- } \\
\text { trial or oth. comparable production } \\
\text { activity. If entity located in tax treaty } \\
\text { country, not on "blacklist", and has } \\
\text { "economic substance". }\end{array}$ \\
\hline France & 1980 & $2003-2004$ & $67 \%$ & - & $\begin{array}{l}>10 \% \text { of shares, interest shares, financial rights or } \\
\text { voting rights. }\end{array}$ & \\
\hline France & 1980 & $2005-2012$ & $50 \%$ & - & $\begin{array}{l}>50 \% \text { of shares, interest shares, financial rights or } \\
\text { voting rights. OR }>5 \% \text { of shares and }>50 \% \text { shares, } \\
\text { interest shares, financial rights or voting rights held } \\
\text { by French ent. }\end{array}$ & $\begin{array}{l}\text { If profits come from an "effective indus- } \\
\text { trial or commercial activity" carried out } \\
\text { in own territory AND }<20 \% \text { of profits } \\
\text { derive from "tainted" income. }\end{array}$ \\
\hline Germany & 1972 & $2003-2007$ & 25 & White- and blacklist ${ }^{30}$ & $\begin{array}{l}>50 \% \text { of shares or voting rights held by resident } \\
\text { shareholders. }\end{array}$ & $\begin{array}{l}<10 \% \text { of overall gross income is passive } \\
\text { and the disregarded amount }<€ 62.000 \\
\text { (both at CFC level and at shareh. level } \\
\text { across subs.). Selected industries are } \\
\text { exempt - such as insurance and banking. }\end{array}$ \\
\hline Germany & 1972 & $2008-2013$ & 25 & White- and blacklist ${ }^{31}$ & $\begin{array}{l}>50 \% \text { of shares or voting rights held by resident } \\
\text { shareholders. }\end{array}$ & $\begin{array}{l}<10 \% \text { of overall gross income is passive } \\
\text { and the disregarded amount }<€ 80.000\end{array}$ \\
\hline
\end{tabular}

Continued on next page

\footnotetext{
29 Only effective since 2009

30 Only function as unofficial and unbinding lists of guidance

31 Only function as unofficial and unbinding lists of guidance
} 
Table 7 - Continued from previous page

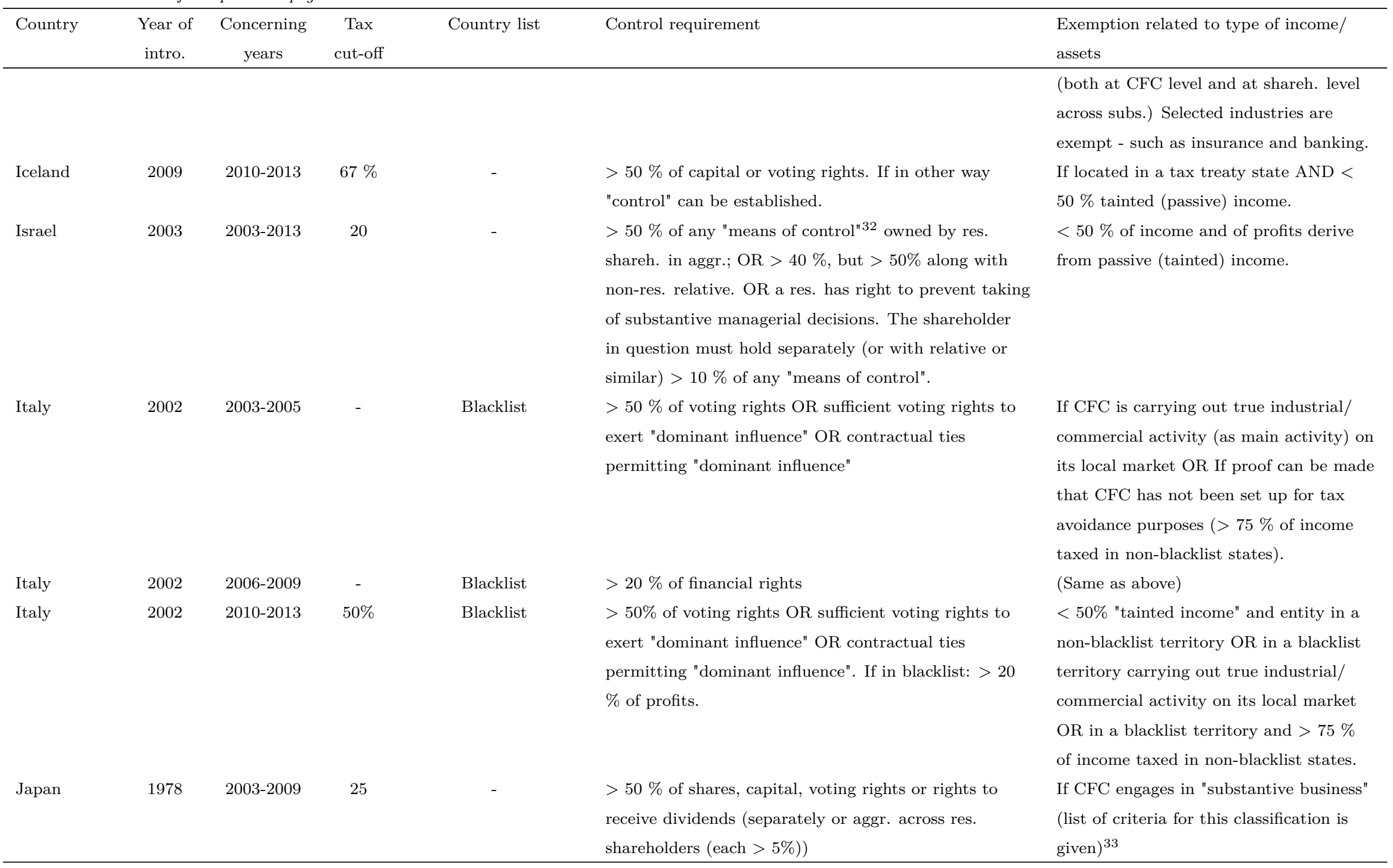

32 The term "means of control" is defined as one of the following: a) right to profits, b) right to appoint director or chief executive officer, c) right to vote in the general meeting, d)right to a share in

the remainder of assets after a dissolution, e) right to instruct someone who has any of the rights listed above.
33 Parts of the CFCs income can still fall under CFC taxation if this income is passive and generated for certain types of assets (interest from bonds, royalties from IP etc.) 
Table 7 - Continued from previous page

\begin{tabular}{|c|c|c|c|c|c|c|}
\hline Country & $\begin{array}{l}\text { Year of } \\
\text { intro. }\end{array}$ & $\begin{array}{c}\text { Concerning } \\
\text { years }\end{array}$ & $\begin{array}{c}\text { Tax } \\
\text { cut-off }\end{array}$ & Country list & Control requirement & $\begin{array}{l}\text { Exemption related to type of income/ } \\
\text { assets }\end{array}$ \\
\hline Japan & 1978 & $2010-2013$ & 20 & - & $\begin{array}{l}>50 \% \text { of shares, capital, voting rights or rights to } \\
\text { receive dividends (separately or aggr. across res. } \\
\text { shareholders (each }>10 \%) \text { ) }\end{array}$ & $\begin{array}{l}\text { If CFC engages in "substantive business" } \\
\text { (list of criteria for this classification is } \\
\text { given) }\end{array}$ \\
\hline Korea & 1996 & $2003-2013$ & $15^{34}$ & Blacklist $^{35}$ & $\begin{array}{l}\text { A "special relationship" } 36 \text { between the resident and the } \\
\text { foreign company must be present. Furthermore the } \\
\text { resident must separately }{ }^{37} \text { own }>10 \% \text { of shares or } \\
\text { capital. }\end{array}$ & $\begin{array}{l}\text { If CFC actively engages in business } \\
\text { through fixed place such as office, shop, } \\
\text { factory etc. }{ }^{38} \text {. Or "De minimis" : If } \\
\text { earned profits < KRW } 200 \text { million. }\end{array}$ \\
\hline Lithuania & 2002 & 2003-2013 & $75 \%$ & Grey- and blacklist & $\begin{array}{l}>50 \% \text { of shares, or other rights to profit (or rights to } \\
\text { acquisition thereof) aggr. across related residents. } \\
\text { Shareholder must separately hold }>10 \% \text { of shares or } \\
\text { other rights to profits (or rights to acquisition thereof) } \\
\text { to be subject to taxation on CFC income. }\end{array}$ & $\begin{array}{l}\text { If income of the CFC comprises }<5 \% \text { of } \\
\text { the income of the shareholding } \\
\text { (controlling) corporation. }\end{array}$ \\
\hline Norway & 1992 & $2003-2013$ & $67 \%$ & White- and blacklist & $\begin{array}{l}>50 \% \text { of shares or capital is owned or controlled } \\
\text { (separately or aggr. across res. shareholders) }\end{array}$ & $\begin{array}{l}\text { If a DTA is in place and income of the } \\
\text { CFC is "not mainly of passive character" }\end{array}$ \\
\hline Portugal & 1995 & $2003-2013$ & $60 \%$ & Blacklist & $\begin{array}{l}\text { Resident shareholder have holding of }>25 \% \text { OR }> \\
10 \% \text { if }>50 \% \text { of share capital held by Portuguese } \\
\text { tax res. entities }\end{array}$ & $\begin{array}{l}\text { Entity excluded if: } 1 .>75 \% \text { of profits } \\
\text { from agricultural/industrial activity in } \\
\text { own juris., or commercial activity not } \\
\text { with Portuguese entities. } 2 \text {. Cannot } \\
\text { engage in specified transactions }{ }^{39} \text {. }\end{array}$ \\
\hline
\end{tabular}

Continued on next page

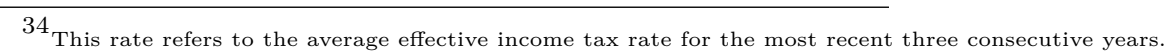

35 Only in the years before 2010 .

36 A "Special relationship" is defined as either of the following: a) ownership of $>50 \%$ of voting shares b) third party owns $>50 \%$ of voting shares of the two parties considered c) common interests through investment, transaction of goods, loan etc. and power to make business decisions on behalf of the company d) common interests through investment, transaction of goods, loan etc. and third party has power to make business decisions on behalf of both parties considered.

${ }^{37}$ When ownership percentage is determined the ownership of the following relatives are counted: spouse, lineal relatives and siblings, spouse of lineal relatives in same household, lineal relatives and siblings of a spouse in the same household.

38 There are a few exceptions to to this rule, namely: a) the exemption does not come into effect if the CFC is doing business in wholesaling, financing, insurance, property rental or business services AND its aggregate revenue and aggregate purchase cost generated from these activities exceeds $50 \%$ of total revenue or total purchase cost b) exemption is not valid if CFC's primary business (i.e. revenue from activity represents more than $50 \%$ of total revenue) is owning stocks, equities or bonds or providing IP rights, leasing ships, aircraft or equipment or making investments in trusts or funds.

39 The business of the corporation musty not involve the following: a. Transactions traditionally related to banking activities. b. Transactions related to insurance business (if income relates to the insurance of assets located mostly outside own jurisdiction). c. Transactions related to equities, other securities, IP, industrial property, knowhow or the rendering of technical assistance. d. Leasing of assets (except landet property in win jurisdiction. 
Table 7 - Continued from previous page

\begin{tabular}{|c|c|c|c|c|c|c|}
\hline Country & $\begin{array}{l}\text { Year of } \\
\text { intro. }\end{array}$ & $\begin{array}{l}\text { Concerning } \\
\text { years }\end{array}$ & $\begin{array}{c}\text { Tax } \\
\text { cut-off }\end{array}$ & Country list & Control requirement & $\begin{array}{l}\text { Exemption related to type of income/ } \\
\text { assets }\end{array}$ \\
\hline South Africa & 2001 & $2008-2013$ & $75 \%$ & - & $\begin{array}{l}>50 \% \text { of participation rights }{ }^{40}, \text { or }>50 \% \text { of voting } \\
\text { rights aggr. across res. persons. (voting rights in listed } \\
\text { companies not counted, and if single res. holds }<5 \% \\
\text { in a listed company also not counted). Shareholder } \\
\text { must separately (or with connected person) hold }>10 \\
\% \text { of participation rights or voting rights } \\
\text { to be subject to CFC taxation. }\end{array}$ & $\begin{array}{l}\text { If CFC has a "place of business" (FBE), } \\
\text { defined by characteristics such as "on } \\
\text { site employees" etc., AND the tainted } \\
\text { income }<5 \% \text { of total amounts accrued } \\
\text { to the CFC attributable to the FBE. }\end{array}$ \\
\hline Spain & 1994 & $2003-2013$ & $75 \% 41$ & Grey list & $\begin{array}{l}>50 \% \text { capital, equity, profits or voting rights } \\
\text { (separately or "group control") }\end{array}$ & $\begin{array}{l}<15 \% \text { of total income is tainted income } \\
\text { OR }<4 \% \text { of total gross income is tainted } \\
\text { income. } 42\end{array}$ \\
\hline Sweden & $\begin{array}{l}2004^{43} \\
/ 1991\end{array}$ & $2004-2013$ & $55 \%$ & $\begin{array}{l}\text { White-, grey- and } \\
\text { blacklist }\end{array}$ & $\begin{array}{l}\text { Holding/having control over }>25 \% \text { of capital or } \\
\text { voting rights (separate or w. entities "in association") }\end{array}$ & $\begin{array}{l}\text { Income assignable to int. shipping } \\
\text { business and shareholder also engaged in } \\
\text { shipping business }\end{array}$ \\
\hline Turkey & 2006 & $2006-2013$ & 10 & - & $\begin{array}{l}>50 \% \text { of capital, share of profit or voting power. } \\
\text { Separately or w. other res. shareh. }\end{array}$ & $\begin{array}{l}<25 \% \text { of gross income is passive OR } \\
\text { annual gross income }<100.000 \mathrm{TL} .\end{array}$ \\
\hline $\mathrm{UK}^{44}$ & 1984 & $2003-2013^{45}$ & $75 \%$ & Grey list & $\begin{array}{l}>50 \% \text { shares, capital or voting power or entitled to } \\
>50 \% \text { of distributed profits (or options to acquire } \\
\text { rights in the future) aggr. across UK res. Further: } \\
\text { each must separately have rights to }>25 \% \text { of profits. }\end{array}$ & $\begin{array}{l}\text { 1. CFC distributes }>90 \% \text { of chargeable } \\
\text { profits to UK res. } 2 . \text { CFC on excluded } \\
\text { countries list AND non-local source } \\
\text { income }<\max (£ 50.000,10 \% \text { of com. } \\
\text { quantified income })^{46} .3 .>35 \% \text { voting }\end{array}$ \\
\hline
\end{tabular}

Continued on next page

40 "Participation rights": The benefits attached to a share in a company, or interest of a similar nature, or to voting rights.

$41 \mathrm{~A}$ CFC resident in a tax haven will per assumption live up to the low tax requirement.

${ }^{42}$ A special exemption applies to foreign holding companies, as passive income from such a source might just be "formally passive" . Requirements regarding participation as well as the source of the income applies.

43 There is some disagreement as to whether the system in place before 2004 could also be classified as a CFC regime. Significant changes were however completed in 2004 .

44 Note that the United Kingdom has undergone major changes to other parts of the corporate tax system in this period - amongst others a shift from a credit system to a dividend exemption system.

45 Small changes were made to the legislation in 2011, including two new exemptions regarding overseas trading and IP companies. The UK CFC regime was more fundamentally reformed in 2013 with the introduction of different "gateways" and a focus on taxing profits deriving from UK activity, rather than worldwide activity. Initial drafts for this reform were published already from 2009, and hence might have been expected by some corporations. Importantly the "low tax threshold" was not altered in this reform, but was re-formulated, now in terms of an exemption instead of a requirement for CFC status.

${ }^{46}$ Commercially quantified income is profits before tax, while non-local source income is gross income. 
Table 7 - Continued from previous page

\begin{tabular}{|c|c|c|c|c|c|c|}
\hline Country & $\begin{array}{l}\text { Year of } \\
\text { intro. }\end{array}$ & $\begin{array}{l}\text { Concerning } \\
\text { years }\end{array}$ & $\begin{array}{c}\text { Tax } \\
\text { cut-off }\end{array}$ & Country list & Control requirement & $\begin{array}{l}\text { Exemption related to type of income/ } \\
\text { assets }\end{array}$ \\
\hline & & & & & & $\begin{array}{l}\text { power allotted the public AND principal } \\
\text { members }{ }^{47} \text { own }<85 \% \text { of voting power. } \\
4 \text {. CFC runs true business in juris. of } \\
\text { residents and management. } 5 \text {. CFC's } \\
\text { transactions do not achieve sign. reduc. } \\
\text { in UK tax (or have this motive) }\end{array}$ \\
\hline USA & 1962 & 2003-2013 & - & - & $\begin{array}{l}>50 \% \text { of total combined voting power or total value } \\
\text { of the stock owned in aggr. by res. shareholders. } \\
\text { Separately shareh. must own }>10 \% \text { of total combined } \\
\text { voting power to be subject to CFC taxation }\end{array}$ & $\begin{array}{l}\text { Income may be excluded if subject to } \\
\text { "high rate of foreign tax". De minimis: } \\
\text { If gross tainted (FBCI) income }<\min (5 \\
\% \text { of gross income, } \$ 1 \text { million })\end{array}$ \\
\hline
\end{tabular}

Hungary also has a CFC regime, but it is only targeted at Hungarian individual shareholders, and not corporations. Hence this regime is not relevant for the analysis in this study, where the focus is on Multinational corporations.

\footnotetext{
${ }^{47}$ A principal member is an entity, who together with associated parties possesses $>5 \%$ of the voting power.
} 